NASA/TM—2013-218091

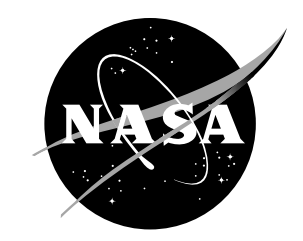

Calcium-Magnesium-Aluminosilicate (CMAS) Reactions and Degradation Mechanisms of Advanced Environmental Barrier Coatings

Nadia L. Ahlborg and Dongming Zhu

Glenn Research Center, Cleveland, Ohio 


\section{NASA STI Program . . . in Profile}

Since its founding, NASA has been dedicated to the advancement of aeronautics and space science. The NASA Scientific and Technical Information (STI) program plays a key part in helping NASA maintain this important role.

The NASA STI Program operates under the auspices of the Agency Chief Information Officer. It collects, organizes, provides for archiving, and disseminates NASA's STI. The NASA STI program provides access to the NASA Aeronautics and Space Database and its public interface, the NASA Technical Reports Server, thus providing one of the largest collections of aeronautical and space science STI in the world. Results are published in both non-NASA channels and by NASA in the NASA STI Report Series, which includes the following report types:

- TECHNICAL PUBLICATION. Reports of completed research or a major significant phase of research that present the results of NASA programs and include extensive data or theoretical analysis. Includes compilations of significant scientific and technical data and information deemed to be of continuing reference value. NASA counterpart of peer-reviewed formal professional papers but has less stringent limitations on manuscript length and extent of graphic presentations.

- TECHNICAL MEMORANDUM. Scientific and technical findings that are preliminary or of specialized interest, e.g., quick release reports, working papers, and bibliographies that contain minimal annotation. Does not contain extensive analysis.

- CONTRACTOR REPORT. Scientific and technical findings by NASA-sponsored contractors and grantees.
- CONFERENCE PUBLICATION. Collected papers from scientific and technical conferences, symposia, seminars, or other meetings sponsored or cosponsored by NASA.

- SPECIAL PUBLICATION. Scientific, technical, or historical information from NASA programs, projects, and missions, often concerned with subjects having substantial public interest.

- TECHNICAL TRANSLATION. Englishlanguage translations of foreign scientific and technical material pertinent to NASA's mission.

Specialized services also include creating custom thesauri, building customized databases, organizing and publishing research results.

For more information about the NASA STI program, see the following:

- Access the NASA STI program home page at http://www.sti.nasa.gov

- E-mail your question to help@sti.nasa.gov

- Fax your question to the NASA STI Information Desk at 443-757-5803

- Phone the NASA STI Information Desk at 443-757-5802

- Write to: STI Information Desk NASA Center for AeroSpace Information 7115 Standard Drive Hanover, MD 21076-1320 
NASA/TM-2013-218091

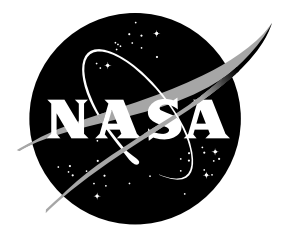

\section{Calcium-Magnesium-Aluminosilicate (CMAS) Reactions and Degradation Mechanisms of Advanced Environmental Barrier Coatings}

Nadia L. Ahlborg and Dongming Zhu

Glenn Research Center, Cleveland, Ohio

Prepared for the

40th International Conference on Metallurgical Coatings and Thin Films (ICMCTF 2013) sponsored by AVS Advanced Surface Engineering Division

San Diego, California, April 29-May 3, 2013

National Aeronautics and

Space Administration

Glenn Research Center

Cleveland, Ohio 44135 
Level of Review: This material has been technically reviewed by technical management.

Available from

NASA Center for Aerospace Information 7115 Standard Drive

Hanover, MD 21076-1320
National Technical Information Service 5301 Shawnee Road Alexandria, VA 22312

Available electronically at http://www.sti.nasa.gov 


\title{
Calcium-Magnesium-Aluminosilicate (CMAS) Reactions and Degradation Mechanisms of Advanced Environmental Barrier Coatings
}

\author{
Nadia L. Ahlborg* and Dongming Zhu \\ National Aeronautics and Space Administration \\ Glenn Research Center \\ Cleveland, Ohio 44135
}

\begin{abstract}
The thermochemical reactions between calcium-magnesium-aluminosilicate- (CMAS-) based road sand and several advanced turbine engine environmnetal barrier coating (EBC) materials were studied. The phase stability, reaction kinetics and degradation mechanisms of rare earth (RE)-silicates $\mathrm{Yb}_{2} \mathrm{SiO}_{5}$, $\mathrm{Y}_{2} \mathrm{Si}_{2} \mathrm{O}_{7}$, and RE-oxide doped $\mathrm{HfO}_{2}$ and $\mathrm{ZrO}_{2}$ under the CMAS infiltration condition at $1500{ }^{\circ} \mathrm{C}$ were investigated, and the microstructure and phase characteristics of CMAS-EBC specimens were examined using Scanning Electron Microscopy (SEM) and X-ray Diffraction (XRD). Experimental results showed that the CMAS dissolved RE-silicates to form crystalline, highly non-stoichiometric apatite phases, and in particular attacking the silicate grain boundaries. Cross-section images show that the CMAS reacted with specimens and deeply penetrated into the EBC grain boundaries and formed extensive low-melting eutectic phases, causing grain boundary recession with increasing testing time in the silicate materials. The preliminary results also showed that CMAS reactions also formed low melting grain boundary phases in the higher concentration RE-oxide doped $\mathrm{HfO}_{2}$ systems. The effect of the test temperature on CMAS reactions of the EBC materials will also be discussed. The faster diffusion exhibited by apatite and RE-doped oxide phases and the formation of extensive grain boundary low-melting phases may limit the CMAS resistance of some of the environmental barrier coatings at high temperatures.
\end{abstract}

\section{Introduction}

The ever-present needs for developing higher efficiency high performance turbine engines have created demand for new hot-section component materials that are lighter and more temperature capable. Current Ni-based superalloys are reaching the upper limit of their temperature capabilities, and so silicon carbide (SiC) fiber-reinforced $\mathrm{SiC} / \mathrm{SiC}$ ceramic matrix composites (CMCs) have been envisioned as alternative next generation turbine engine hot-section materials (Ref. 1). Silicon-based ceramics and composites are desirable because they have low density, superior strength and oxidation resistance in high temperature oxidizing environments. However, a major issue with Si-based materials is their vulnerability to corrosion and performance degradation in combustion water vapor containing environments due to volatilization of the protective silica $\left(\mathrm{SiO}_{2}\right)$ scales, leading to recession of the ceramics and strength degradation under combined thermo-mechanical loading conditions. An environmental barrier coating (EBC) can be used to prevent the $\mathrm{SiC} / \mathrm{SiC} \mathrm{CMC}$ from reacting with water vapor (Refs. 1 to 3). Advanced $\mathrm{HfO}_{2}, \mathrm{ZrO}_{2}$, and rare earth silicate (RE silicate) EBC systems have also been developed, achieving significantly improved temperature capability and environmental protection of $\mathrm{SiC} / \mathrm{SiC} \mathrm{CMCs} \mathrm{(Refs.} 4$ to 6).

The significantly higher operating temperatures envisioned above $1500{ }^{\circ} \mathrm{C}$ for next generation turbine engine hot-section components impose additional material design constraints and raise serious component environmental durability issues. Many common silicon-containing sand dust and volcano ash materials can melt at approximately $1200{ }^{\circ} \mathrm{C}$. During engine operation, these materials deposit on the EBC and form glassy melts of calcium-magnesium aluminosilicate (CMAS), which can significantly reduce the

\footnotetext{
*NASA Glenn Research Center, summer intern from The Ohio State University.
} 
silicon-based EBC temperature capability. This molten CMAS interacts chemically and mechanically with the EBC to cause premature coating failure. Thus when designing EBC materials, it is critical to understand the high-temperature interactions between the coating materials and CMAS in order to create CMAS-resistant coatings. Research work has been done to determine the mechanisms by which CMAS can cause failure and performance degradations in yttria stabilized zirconia thermal barrier coatings (Refs. 7 and 8) and early generation EBCs (Refs. 9 to 12).

The objective of the present paper is to investigate the stability of candidate rare earth silicates and rare earth oxide-doped $\mathrm{HfO}_{2}$ and $\mathrm{ZrO}_{2}$ environmental barrier coatings in contact with CMAS at high temperature. The emphasis is placed on the reactions and degradation mechanisms between CMAS and EBC materials particularly at $1500{ }^{\circ} \mathrm{C}$, and compared with the results at $1300{ }^{\circ} \mathrm{C}$. The current work is thus aiming at providing information on the CMAS resistance of RE silicates and RE oxide-doped $\mathrm{HfO}_{2}$ and $\mathrm{ZrO}_{2}$ systems.

\section{Experimental Materials and Methods}

The two primary EBC materials investigated in this study were ytterbium monosilicate $\left(\mathrm{Yb}_{2} \mathrm{SiO}_{5}\right)$ and yttrium disilicate $\left(\mathrm{Y}_{2} \mathrm{Si}_{2} \mathrm{O}_{7}\right)$. These materials were NASA-designed and processed in the form of plasmahomogenized hollow-sphere (HOSP) powders to NASA powder specifications by Sulzer Metco (US), Westbury, New York, USA. In addition to the RE silicates, HOSP NASA four-component $\mathrm{HfO}_{2^{-}}$ $23.9 \mathrm{~mol} \%(\mathrm{Gd}, \mathrm{Yb}, \mathrm{Y})_{2} \mathrm{O}_{3}$ and six-component $\mathrm{ZrO}_{2}-4.4 \mathrm{~mol} \%(\mathrm{Y}, \mathrm{Gd}, \mathrm{Yb})_{2} \mathrm{O}_{3}-2.6 \mathrm{~mol} \%\left(\mathrm{TiO}_{2}+\mathrm{Ta}_{2} \mathrm{O}_{5}\right)$ compositions (Ref. 6) were also investigated.

Two types of samples were produced for this study. For the first kind, EBC powders were sintered using a hot press technique at $1500{ }^{\circ} \mathrm{C}$ and $103 \mathrm{MPa}$ load in a vacuum environment to create dense, monolithic slabs $\sim 4 \mathrm{~mm}$ thick or discs $\sim 2 \mathrm{~mm}$ thick, which were then cut into several specimens. Each sample was prepared for CMAS exposure by polishing the surface of interest using 320-grit SiC paper and cleaning the surface with ethanol. To provide a baseline understanding for material behavior at $1500{ }^{\circ} \mathrm{C}$, one specimen of each material was heat treated in air for $50 \mathrm{hr}$ at $1500^{\circ} \mathrm{C}$. A model CMAS frit containing $35 \mathrm{~mol} \% \mathrm{CaO}-10 \mathrm{~mol} \% \mathrm{MgO}-7 \mathrm{~mol} \% \mathrm{Al}_{2} \mathrm{O}_{3}-48 \mathrm{~mol} \% \mathrm{SiO}_{2}$ and minor amounts of $\mathrm{Fe}_{2} \mathrm{O}_{3}$ and $\mathrm{NiO}$ was received from GE Aviation, Evendale, Ohio, USA. The CMAS frit was mixed with ethanol to form a paste and placed on each specimen surface to give a CMAS surface concentration of $\sim 40 \mathrm{mg} / \mathrm{cm}^{2}$. The specimens were placed in an alumina crucible and heat treated in air for 5, 50,100,150, or $200 \mathrm{~h}$ at $1500{ }^{\circ} \mathrm{C}$. Every $50 \mathrm{~h}$, the furnace was cooled to room temperature and the samples were removed and photographed. Because of observed volatility of CMAS and the reaction products, for samples tested longer than $50 \mathrm{~h}$, an additional $40 \mathrm{mg} / \mathrm{cm}^{2}$ CMAS was applied to the sample surface every $50 \mathrm{~h}$. Compared to a single application of CMAS, this testing procedure better simulates engine operation where the source of CMAS is continuously available. To provide a better understanding of the CMAS$\mathrm{EBC}$ reaction, additional tests were conducted for both of the RE-silicate materials at $1300{ }^{\circ} \mathrm{C}$ for $50 \mathrm{~h}$.

The second type of sample was produced by mechanically mixing 25 and $30 \mathrm{wt} \%$ CMAS frit with $\mathrm{Yb}_{2} \mathrm{SiO}_{5}$ and $\mathrm{Y}_{2} \mathrm{Si}_{2} \mathrm{O}_{7}$ EBC powders, respectively. The CMAS amounts were adjusted to reflect a higher concentration that would occur in a thin turbine coating system. The mixtures were sintered via hot press at $1050{ }^{\circ} \mathrm{C}$ and $103 \mathrm{MPa}$ load in vacuum using a $\mathrm{SiC} / \mathrm{SiC} \mathrm{CMC}$ as a backing to produce two $1 \mathrm{~mm}$ thick RE-silicate + CMAS blend coating specimens onto CMC substrates. It was thought that these samples would more accurately represent the original CMAS composition in the closed, high pressure turbine section environment because the CMAS would volatilize less and thus react more completely with the EBCs when conducting the tests at such high temperatures. 
Following testing, specimens were examined using x-ray diffraction (XRD) to determine phase structure using $\mathrm{Cu} \mathrm{K} \alpha$ radiation with a wavelength of $1.541 \AA$. Each specimen was then sectioned using a low-speed diamond saw. One half of the specimen was mounted and polished using standard metallographic techniques and examined using a field-emission scanning electron microscope (SEM). The other half was reserved for examination of the surface with electron microscopy. Qualitative chemical compositions were obtained from surfaces and cross-sections using electron dispersive spectroscopy (EDS).

\section{Experimental Results}

\section{$\mathrm{Yb}_{2} \mathrm{SiO}_{5}-\mathrm{CMAS}$ Surface Reactions}

Figure 1 shows cross-sectional images of the $\mathrm{Yb}_{2} \mathrm{SiO}_{5}$ in the as-sintered condition and after $50 \mathrm{~h}$ of heat treatment in air at $1500{ }^{\circ} \mathrm{C}$. There was little change in microstructure observed over time.

Figure 2 shows images of $\mathrm{Yb}_{2} \mathrm{SiO}_{5}$ before and after CMAS reactions. The dark areas in the $5 \mathrm{~h}$ tested specimen (Fig. 2(b)) are $\mathrm{Yb}_{2} \mathrm{SiO}_{5}$-CMAS reaction products. There is visibly much less of this reacted material on the 50 and $200 \mathrm{~h}$ tested specimens, suggesting that the CMAS components may be highly volatile at $1500{ }^{\circ} \mathrm{C}$ and atmospheric pressure in air.

SEM images of $\mathrm{Yb}_{2} \mathrm{SiO}_{5}$ reacted with CMAS for $50 \mathrm{~h}$ are shown in Figure 3. EDS was used to qualitatively determine the elemental composition in each region of the micrographs. CMAS reacted with the $\mathrm{Yb}_{2} \mathrm{SiO}_{5}$ to form a Ca-Yb-Si-containing layer with an average thickness of $\sim 60$ to $100 \mu \mathrm{m}$. The surface of this reaction layer (Fig. 3(b)) consisted of roughly hexagonal-shaped grains with an average diameter of $17 \mu \mathrm{m}$. Figure 4 shows cross-sectional images of $\mathrm{Yb}_{2} \mathrm{SiO}_{5}$ reacted with CMAS for $200 \mathrm{~h}$. The heavily reacted surface layer had the same approximate composition, crystal structure, and average thickness as in Figure 3(a). The enlarged regions in Figures 4(b) and (d) have eutectic microstructures, indicating that they solidified from a low-melting liquid due to the higher CMAS content. EDS shows that the lighter phase of this eutectic is rich in $\mathrm{Al}, \mathrm{Mg}, \mathrm{Si}$, and $\mathrm{Yb}$, while the dark phase is rich in $\mathrm{Al}, \mathrm{Ca}, \mathrm{Mg}$, and Si. As apparent from Figure 4(c), these low-melting particles are located between grains, providing evidence for preferential CMAS attack at grain boundaries. These particles were found to penetrate the entire specimen cross-section, which has a bulk thickness of $\sim 4 \mathrm{~mm}$.

XRD was used to determine that the reaction layers in Figures 3(a) and 4(a) had a crystal structure similar to calcium-ytterbium-silicate-oxyapatite $\left(\mathrm{Ca}_{2} \mathrm{Yb}_{8}\left(\mathrm{SiO}_{4}\right)_{6} \mathrm{O}_{2}\right)$, a variation of the mineral apatite. The $\mathrm{X}$-ray scan of the $200 \mathrm{~h}$-reacted $\mathrm{Yb}_{2} \mathrm{SiO}_{5}$ is compared to a known apatite structure in Figure 5. The Al, $\mathrm{Yb}$, $\mathrm{Mg}$, Ca-containing grain boundary phases may be too small in quantity and/or preferred orientation with glass phases to contribute significantly to the diffraction pattern.

In order to better understand the grain size behavior, volatility, and surface melting of rare earth silicates, CMAS surface reaction treatments were carried out for $5 \mathrm{~h}$ at $1500^{\circ} \mathrm{C}$ and $50 \mathrm{~h}$ at $1300^{\circ} \mathrm{C}$ in air, and compared to 50 and $200 \mathrm{~h}$ treatments at $1500{ }^{\circ} \mathrm{C}$. The XRD profile of the $5 \mathrm{~h}$ reacted specimen was found to be almost identical to the $200 \mathrm{~h}$ reacted sample in Figure 5, indicating that these were $\mathrm{Ca}_{2} \mathrm{Yb}_{8}\left(\mathrm{SiO}_{4}\right)_{6} \mathrm{O}_{2}$ grains. The surface of this specimen (Fig. 6(a)) has roughly hexagonal grains similar to those in the $50 \mathrm{~h}$ CMAS-reacted specimen (Fig. 3(b)). This suggests that the initially fast CMAS reaction kinetics and less further degradation of the specimens due to the CMAS volatility at the high temperatures and therefore the loss of available CMAS for reactions. The apatite grains appear to grow from an amorphous, CMAS-rich melt matrix, demonstrating that the apatite surface layer forms from a CMASrich melt. In contrast, the surface of the $1300{ }^{\circ} \mathrm{C}$ reacted specimen is glassy, with few notable microstructural features. This indicates significantly less reactions and slower kinetics at the lower testing temperatures. 


\section{$\mathrm{Y}_{2} \mathrm{Si}_{2} \mathrm{O}_{7}-\mathrm{CMAS}$ Surface Reactions}

Figure 7 shows images of $\mathrm{Y}_{2} \mathrm{Si}_{2} \mathrm{O}_{7}$ specimens before and after reacting with CMAS for various times at $1500{ }^{\circ} \mathrm{C}$. The same issue of CMAS volatility at atmospheric pressure observed in $\mathrm{Yb}_{2} \mathrm{SiO}_{5}$ was also observed for this material at such a high test temperature. Figure 8 shows $\mathrm{SEM}$ images of $\mathrm{Y}_{2} \mathrm{Si}_{2} \mathrm{O}_{7}$ reacted with CMAS for $50 \mathrm{~h}$. The region shown in Figure 8(a) represents a portion of the $\sim 1 \mathrm{~mm}$ thick wellmelted layer in contact with high CMAS concentration, which has been converted from $\mathrm{Y}_{2} \mathrm{Si}_{2} \mathrm{O}_{7}$ to a $\mathrm{Ca}-\mathrm{Si}$-Y-rich reaction product with isolated Si-rich regions. The surface of reaction layer (Fig. 8(b)) consists of angular, needle-like grains. SEM micrographs of $\mathrm{Y}_{2} \mathrm{Si}_{2} \mathrm{O}_{7}$ reacted with CMAS for $200 \mathrm{~h}$ are shown in Figure 9. The light colored phase shown in Figure 9(a) is a portion of the $\sim 1 \mathrm{~mm}$ thick melted layer and is rich in $\mathrm{Ca}, \mathrm{Si}$, and $\mathrm{Y}$. The darker phases located between the lighter grains are rich in $\mathrm{Al}, \mathrm{Si}$, and $\mathrm{Y}$ and can be found throughout the entire $\sim 4 \mathrm{~mm}$ thick cross-section. Unlike the $\mathrm{Yb}_{2} \mathrm{SiO}_{5}-\mathrm{CMAS}$ reaction products, these grain boundary phases are not visible in the surface images (Fig. 9(b)), possibly due to even higher volatility in the $\mathrm{Y}, \mathrm{Al}, \mathrm{Ca}, \mathrm{Mg}$, Si-containing phases. XRD identifies the Ca-containing $\mathrm{Y}_{2} \mathrm{Si}_{2} \mathrm{O}_{7}$-CMAS reaction product as calcium-yttrium-silicate-oxyapatite $\left(\mathrm{Ca}_{2} \mathrm{Y}_{8}\left(\mathrm{SiO}_{4}\right)_{6} \mathrm{O}_{2}\right)$, as shown in Figure 10. This material has a very similar structure to the $\mathrm{Yb}_{2} \mathrm{SiO}_{5}-\mathrm{CMAS}$ reaction layer.

It can be seen from Figure 11(a) that the $\mathrm{Y}_{2} \mathrm{Si}_{2} \mathrm{O}_{7}$ reacted with CMAS for $5 \mathrm{~h}$ at $1500{ }^{\circ} \mathrm{C}$ has a surface microstructure nearly identical to the $50 \mathrm{~h}$ CMAS reacted specimen in Figure 8(b) with the same amount CMAS applied. As with $\mathrm{Yb}_{2} \mathrm{SiO}_{5}$, the result suggests that the reaction occurred fast in the initial a few hours, and the reaction and CMAS loss due to its volatility prevented further significant more reactions in the test condition. The surface of the $1300{ }^{\circ} \mathrm{C}$ reacted sample in Figure 11(b) contains apatite grains of similar shape to the $1500{ }^{\circ} \mathrm{C}$ CMAS-reacted specimens, while un-reacted glass phase CMAS seemed still present. The XRD profile of this specimen is nearly identical to Figure 10, showing the crystalline calcium-yttrium-silicate-oxyapatite $\left(\mathrm{Ca}_{2} \mathrm{Y}_{8}\left(\mathrm{SiO}_{4}\right)_{6} \mathrm{O}_{2}\right)$ phase.

\section{RE-Silicate + CMAS Blend}

The hot-pressed rare earth silicate-CMAS blends are shown before and after heat treatment in Figure 12. Before heat treatment, both specimens appear dense and have a mottled appearance. Heat treatment at $1500{ }^{\circ} \mathrm{C}$ results in complete melting of both samples. This melt partially infiltrated the porous alumina crucible to penetrate and react with a portion of the ceramic brick beneath it. The experiments approximately determined upper temperature limits of the coating materials in contact with CMAS, and showing some extensive melting of the $\mathrm{Yb}_{2} \mathrm{SiO}_{5}$ and $\mathrm{Y}_{2} \mathrm{Si}_{2} \mathrm{O}_{7}$ specimens at the high 25 to $30 \mathrm{wt} \% \mathrm{CMAS}$ concentrations at $1500{ }^{\circ} \mathrm{C}$.

\section{RE-Oxide Doped $\mathrm{HfO}_{2}$ - and $\mathrm{ZrO}_{2}$-CMAS Surface Reactions}

Images of the RE-oxide doped $\mathrm{HfO}_{2}$ reacted with CMAS for $100 \mathrm{~h}$ are shown in Figure 13. Based on initial examinations, the large, light colored grains contain $\mathrm{HfO}_{2}$ with a much lower RE-oxide concentration than the original as-processed coating material. The darker grain boundary phases are rich in both CMAS elements and RE elements. These RE-rich grain boundary phases penetrated through the entire specimen, which had a bulk thickness of $\sim 2 \mathrm{~mm}$.

Figure 14 shows images of the six-component $\mathrm{ZrO}_{2}$ reacted with CMAS for $100 \mathrm{~h}$. The EDS analysis indicates that the large, white grains visible in the cross-section and surface images contain mainly $\mathrm{ZrO}_{2}$. The dark grain boundary regions appear to be rich in $\mathrm{Si}$ and $\mathrm{Zr}$. No $\mathrm{Ca}, \mathrm{Mg}$, or $\mathrm{Al}$ was detected in the sample cross-section of surface, possibly due to high volatility of the unreacted CMAS components. 


\section{Discussion}

\section{RE-Silicates}

The main mechanism of CMAS penetration in the low CMAS concentration surface reaction tests appears to be grain boundary attack. As mentioned in more detail later, some surface melting may have occurred at relatively short CMAS exposure times during which CMAS concentration was high. High CMAS volatility likely reduced the CMAS surface concentration at longer exposure times. In the $\mathrm{Yb}_{2} \mathrm{SiO}_{5}$ specimens, the widening of the grain boundary regions containing low-melting eutectics with testing time implies continuing dissolution of the rare earth $(\mathrm{Yb})$ and recession of the grain surfaces even when the overall CMAS surface concentration has decreased due to CMAS volatilization. In both materials, low melting grain boundary phases were observed throughout the bulk thickness of the $200 \mathrm{~h}$ reacted specimens, demonstrating overall poor CMAS resistance, particularly along the grain boundaries, at the test temperatures. Because EBC layers generally have a thickness no greater than $200 \mu \mathrm{m}$, CMAS would penetrate the entire RE silicate EBC top coat quickly, causing the EBC to fail and also exposing the intermediate and bond coat layers to CMAS and other environment attack.

$\mathrm{Y}_{2} \mathrm{Si}_{2} \mathrm{O}_{7}$ appears to have suffered a more severe reaction, possibly due to its higher $\mathrm{SiO}_{2}$ concentration. The needle-like grains in the surface images (Figs. 8(b), 9(b), and 11(a)) of $\mathrm{Y}_{2} \mathrm{Si}_{2} \mathrm{O}_{7}$ are formed from a liquid phase, indicating at least the surface of the $\mathrm{EBC}$ experiences localized melting at $1500{ }^{\circ} \mathrm{C}$. This also appears to be the case for $\mathrm{Yb}_{2} \mathrm{SiO}_{5}$, as the $5 \mathrm{~h} \mathrm{CMAS} \mathrm{experiments} \mathrm{confirmed} \mathrm{localized}$ melting of the $\mathrm{Yb}_{2} \mathrm{SiO}_{5}$ and $\mathrm{Y}_{2} \mathrm{Si}_{2} \mathrm{O}_{7}$ surfaces in contact with high CMAS concentrations. However, more work is under way to explain the difference in grain morphology and grain growth kinetics. The $\mathrm{Y}_{2} \mathrm{Si}_{2} \mathrm{O}_{7^{-}}$ CMAS reaction kinetics appeared faster than the $\mathrm{Yb}_{2} \mathrm{SiO}_{5}$-CMAS kinetics, as evidenced by the fully formed apatite grains on the $5 \mathrm{~h}$ reacted $\mathrm{Y}_{2} \mathrm{Si}_{2} \mathrm{O}_{7}$ specimen and the partially formed apatite grains in the $5 \mathrm{~h}$ reacted $\mathrm{Yb}_{2} \mathrm{SiO}_{5}$ specimen. CMAS attack on $\mathrm{Y}_{2} \mathrm{Si}_{2} \mathrm{O}_{7}$ appears to be a significant problem even at $1300{ }^{\circ} \mathrm{C}$, as demonstrated by the extensive localized melting and formation of Y-containing apatite grains on the specimen surface (Fig. 11(b)). Conversely, $\mathrm{Yb}_{2} \mathrm{SiO}_{5}$ does not display the same aggressive CMAS attack at $1300{ }^{\circ} \mathrm{C}$, which can be seen the lack of a crystalline apatite reaction product (Fig. 6(b)) during the short CMAS exposure.

The CMAS volatility observed in the CMAS surface reaction tests may be unrealistic, as the effective compositions of a localized CMAS source may change rapidly in the $1500{ }^{\circ} \mathrm{C}$ air furnace test conditions and no constant CMAS concentration is maintained during the given testing cycle times. The closed turbine section environment and continuous deposition of CMAS during the engine operation would lessen CMAS volatility, effectively raising the CMAS concentration on the EBC surface and thus likely promoting even more severe CMAS infiltration and attack. In this way, the rare earth silicate-CMAS blend experiments represent a more realistic scenario and help determine the upper temperature limit of the CMAS concentrations. In these tests, the CMAS dissolved the entire EBC specimen, including partially the $\mathrm{SiC} / \mathrm{SiC} \mathrm{CMC}$ substrates. This is an extreme demonstration of the possible catastrophic effects of CMAS on EBCs and turbine section components. More work must be done to determine the upper CMAS concentration limits that RE-silicates and other candidate EBC materials can endure for their designed lifetimes without catastrophic failure.

The RE silicate-CMAS reaction layers observed in the coating experiments suggest very fast transport of CMAS into the bulk grains of the specimens via a solid state diffusion process. An effort was made to explain this fast diffusion by examining the stoichiometry of the apatite reaction layers. An atomic number-absorption-fluorescence (ZAF) technique was used to produce approximate semi-quantitative molar percentages of oxides from the EDS data collected from the $\mathrm{Yb}_{2} \mathrm{SiO}_{5}-\mathrm{CMAS}$ and $\mathrm{Y}_{2} \mathrm{Si}_{2} \mathrm{O}_{7}-\mathrm{CMAS}$ reacted specimens. These molar percentages were then used to determine the ratio of alkaline earth oxides (AE oxides) to RE oxides in the apatite reaction products. This ratio is shown plotted as a function of CMAS reaction time in Figure 15. Stoichiometric apatite has an AE oxide-RE oxide ratio of 0.5. Form the composition standpoint, the non-stoichiometric $\mathrm{Ca}_{2} \mathrm{Yb}_{8}\left(\mathrm{SiO}_{4}\right)_{6} \mathrm{O}_{2}$ appears to be $\mathrm{Yb}_{2} \mathrm{O}_{3}$-lean (with a more oxygen vacant sublattice), while the $\mathrm{Ca}_{2} \mathrm{Y}_{8}\left(\mathrm{SiO}_{4}\right)_{6} \mathrm{O}_{2}$ appears $\mathrm{Y}_{2} \mathrm{O}_{3}$-rich (with an $\mathrm{AE}$ vacant sublattice). 
The modified phase diagram shown in Figure 16 indicates the shifted compositions of the two reaction products. The non-stoichiometric materials contain high concentration anion and cation vacancies and defects, which may substantially increase the rate of CMAS element diffusion in the solid material.

\section{RE-Oxide Doped $\mathrm{HfO}_{2}$ and $\mathrm{ZrO}_{2}$}

The doped $\mathrm{HfO}_{2}$ and $\mathrm{ZrO}_{2}$ specimens generally exhibited less melting as compared to RE-silicates thus may have showed better CMAS phase stability than the RE-silicates. In the case of high rare earth element doped $\mathrm{HfO}_{2}$, the CMAS appears to penetrate the specimen at grain boundaries and maybe forming higher melting RE-aluminosilicate phases. The low concentration of RE elements in the $\mathrm{HfO}_{2}$ bulk grains indicates that these elements also substantially dissolve into the CMAS grain boundary melts to form the grain boundary reaction phases. Unlike the rare earth silicates, however, the doped $\mathrm{HfO}_{2}$ seems to react with CMAS very little but seemed also recessed due to loss of RE elements.

The doped $\mathrm{ZrO}_{2}$ had much lower dopant concentrations and exhibited the least reaction and maybe the best CMAS resistance of the materials studied. The lack of $\mathrm{Ca}, \mathrm{Mg}$, and $\mathrm{Al}$ in the bulk specimen suggests that the unreacted CMAS volatilized during the course of each $50 \mathrm{~h}$ heat treatment. Experiments involving higher CMAS concentrations will have to be done to fully understand the interaction between CMAS and this six-component $\mathrm{ZrO}_{2}$ composition.

\section{Summary and Conclusions}

The thermochemical reactions at $1500{ }^{\circ} \mathrm{C}$ between calcium-magnesium-aluminosilicate- (CMAS) and several EBC materials were studied. After $50 \mathrm{~h}, \mathrm{Yb}_{2} \mathrm{SiO}_{5}$ and $\mathrm{Y}_{2} \mathrm{Si}_{2} \mathrm{O}_{7}$ developed a locally melted, $\mathrm{Ca}$ - and RE-containing reaction layer from which non-stoichiometric apatite-like grains precipitated. CMAS penetrated the specimen preferentially at grain boundaries and dissolved the EBC material to form low-melting grain boundary pockets. After $200 \mathrm{~h}$, these low melting phases extended through the entire specimen, indicating that CMAS penetrated the bulk thickness of $\sim 4 \mathrm{~mm}$. $\mathrm{Y}_{2} \mathrm{Si}_{2} \mathrm{O}_{7}$ appears to react more quickly with CMAS forming even lower melting phases than $\mathrm{Yb}_{2} \mathrm{SiO}_{5}$. RE-silicate +25 to $30 \mathrm{wt} \%$ CMAS specimens were fully melted after $50 \mathrm{~h}$ heat treatment at $1500{ }^{\circ} \mathrm{C}$, indicating that there is an upper limit to the allowable CMAS concentration in these materials. RE-oxide doped $\mathrm{HfO}_{2}$ and $\mathrm{ZrO}_{2}$ demonstrated better CMAS reaction and phase stability than the RE-silicates, although appears that high RE-oxide dopant concentration still facilitated severe grain boundary CMAS attack in $\mathrm{HfO}_{2}$ and the grain boundary surface recession. Low rare earth dopant $\mathrm{ZrO}_{2}$ appeared relatively stable and unreacted under the experimental conditions, and the effect of transition metal dopants Ta and Ti on CMAS resistance is a future topic to be studied. Higher CMAS exposure and some controlled coating experiments must be carried out to fully understand the EBC material's CMAS-resistance capabilities.

\section{References}

1. Spitsberg, I. and Steibel, J. "Thermal and Environmental barrier Coatings for SiC/SiC CMCs in Aircraft Engine Applications," International Journal of Applied Ceramic Technology, Vol. 1, No. 4, 2004, pp. 291-301.

2. Lee, K.N. "Current Status of Environmental Barrier Coatings for Si-Based Ceramics," Surface and Coatings Technology, Vol. 133-134, Nov. 2000, pp. 1-7.

3. Lee, K.N., et al. "Upper Temperature limit of Environmental Barrier Coatings Based on Mullite and BSAS," Journal of the American Ceramic Society, Vol. 86, No. 8, 2003, pp. 1290-1306. 
4. D. Zhu, R.A. Miller, and D.S. Fox, "Thermal and Environmental Barrier Coating Development for Advanced Propulsion Engine Systems," AIAA-2007-2130, 2007. 48th AIAA/ASME/ASCE/ AHS/ASC Structures, Structural Dynamics and Materials Conference, v 5, p 5121-5135, 2007.

5. D. Zhu, N.P. Bansal, R.A. Miller, "Thermal conductivity and stability of $\mathrm{HfO}_{2}-\mathrm{Y}_{2} \mathrm{O}_{3}$ and $\mathrm{La}_{2} \mathrm{Zr}_{2} \mathrm{O}_{7}$ evaluated for $1650{ }^{\circ} \mathrm{C}$ thermal/environmental barrier coating applications," Advances in Ceramics Matrix Composites IX, Ceramic Transactions, Volume 153, p 331-343, 2004.

6. D. Zhu and R.A. Miller, "Multi-functionally graded environmental barrier coatings for Si-based ceramic components," Provisional patent application No. 60/712,605, August 26, 2005; US Patent Application No. 11/510 573, August 28, 2006. U.S. Patent No. 7,740,960 B1, June 2010.

7. Mercer, C., Faulhaber, S., Evans, A.G., Darolina, R. "A delamination mechanism for thermal barrier coatings subject to calcium-magnesium-alumino-silicate (CMAS) infiltration," Acta Materialia, Vol. 53, 2005, pp. 1029-1039.

8. Kramer, S., Yang, J., Levi, C.G., "Thermochemical Interaction of Thermal Barrier Coatings With Molten $\mathrm{CaO}-\mathrm{MgO}-\mathrm{Al}_{2} \mathrm{O}_{3}-\mathrm{SiO}_{2}$ (CMAS) Deposits," Journal of the American Ceramic Society., Vol. 89, No. 10, 2006, pp. 3167-3175.

9. Grant, K.M., Kramer, S., Lofvander, J.P.A., Levi, C.G., "CMAS Degradation of Environmental Barrier Coatings," Surface and Coatings Technology, Vol. 202, July 2007, pp. 653-657.

10. Harder, B.J. et al., "Chemical and Mechanical Consequences of Environmental Barrier Coating Exposure to Calcium-Magnesium-Aluminosilicate," Journal of the American Ceramic Society., Vol. 94, June 2011, pp. 178-185.

11. C.G. Levi, J.W. Hutchinson, M.H. Vidal-Setif, C.A. Johnson, "Environmental Degradation of TBCs by Molten Salt," MRS Bulletin, Vol. 37, Issue 10, October 2012, pp. 932-941.

12. D.S. Miladinovich.; D. Zhu, "Mechanical Properties and Durability of Advanced Environmental Barrier Coatings in Calcium-Magnesium-Alumino-Silicate Environments," The 35th International Conference on Advanced Ceramics and Composites Daytona Beach, Florida 23-28, Jan. 2011.

13. G.J. McCarthy, "Crystal chemistry of the rare earths in solidified high level nuclear wastes;" pp. 665-676 in Proc. Rare Earth Res. Conf., 12th, Vail, Colorado, July 18-22, 1976, Vol. 2. Edited by C.E. Lundin, University of Denver, Denver, Colorado, 1976.
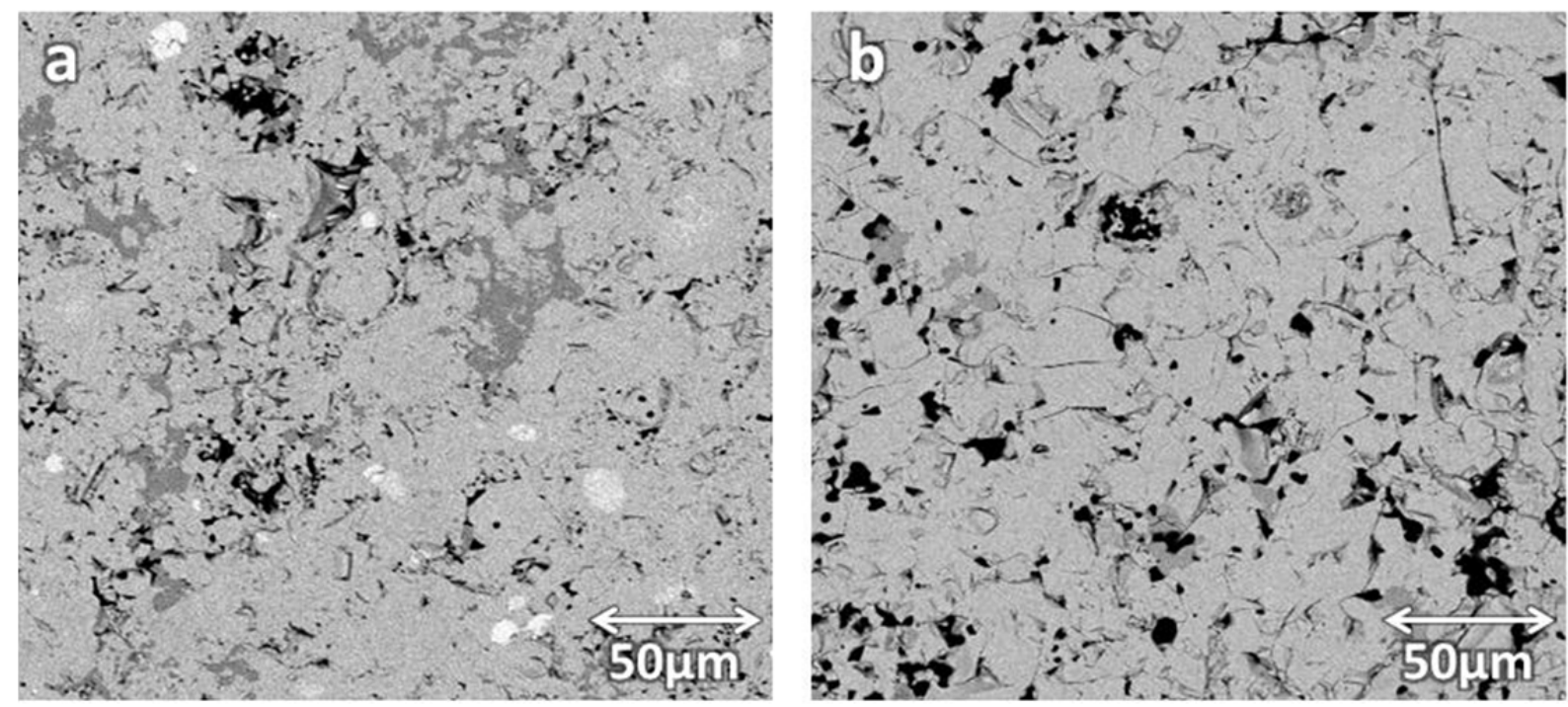

Figure 1.-Sintered and as-processed $\mathrm{Yb}_{2} \mathrm{SiO}_{5}$. Cross-section SEM Back-Scattered Electron (BSE) images of $\mathrm{Yb}_{2} \mathrm{SiO}_{5}(\mathrm{a})$ as-sintered; and (b) after $50 \mathrm{~h}$ heat treatment at $1500{ }^{\circ} \mathrm{C}$ in air. 

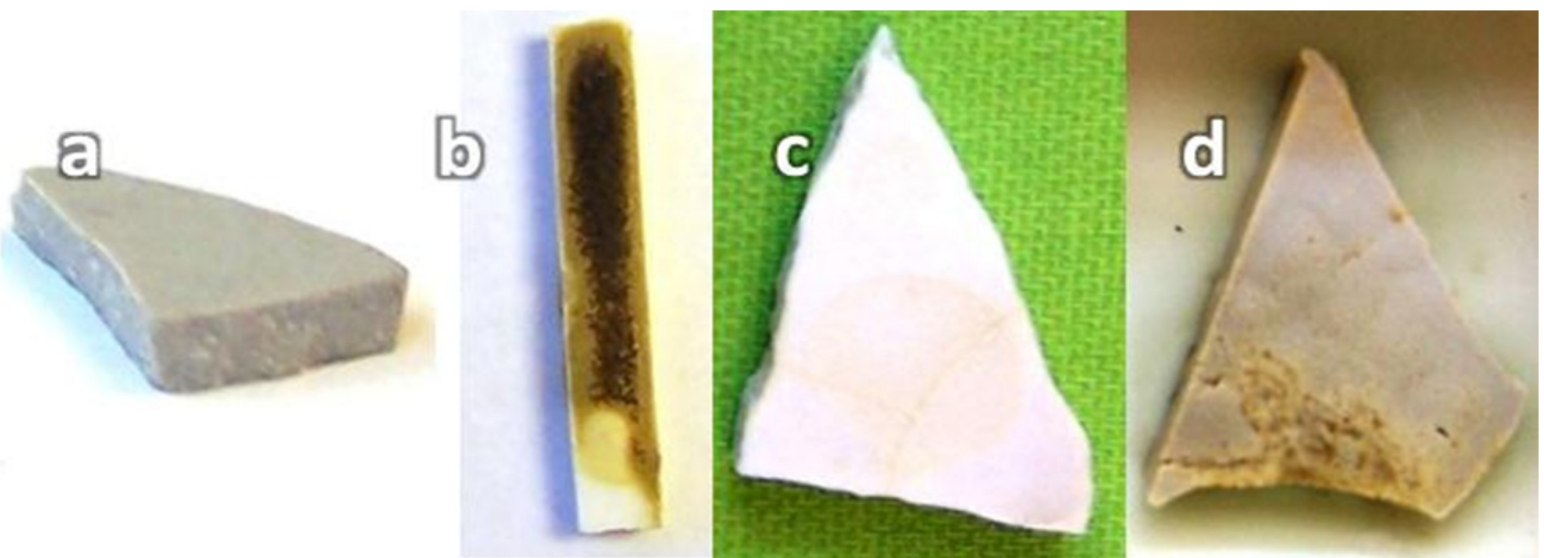

Figure 2.- $-\mathrm{Yb}_{2} \mathrm{SiO}_{5}$ reacted with CMAS. Macro-photographs of $\mathrm{Yb}_{2} \mathrm{SiO}_{5}$ specimens (a) as-sintered; and reacted with CMAS for (b) $5 \mathrm{~h}$, (c) $50 \mathrm{~h}$, and (d) $200 \mathrm{~h}$. There is visibly much less of the reacted material on the $50 \mathrm{~h}$ and $200 \mathrm{~h}$ tested specimens, suggesting that the CMAS components may be highly volatile at $1500^{\circ} \mathrm{C}$ in atmospheric pressure in air.
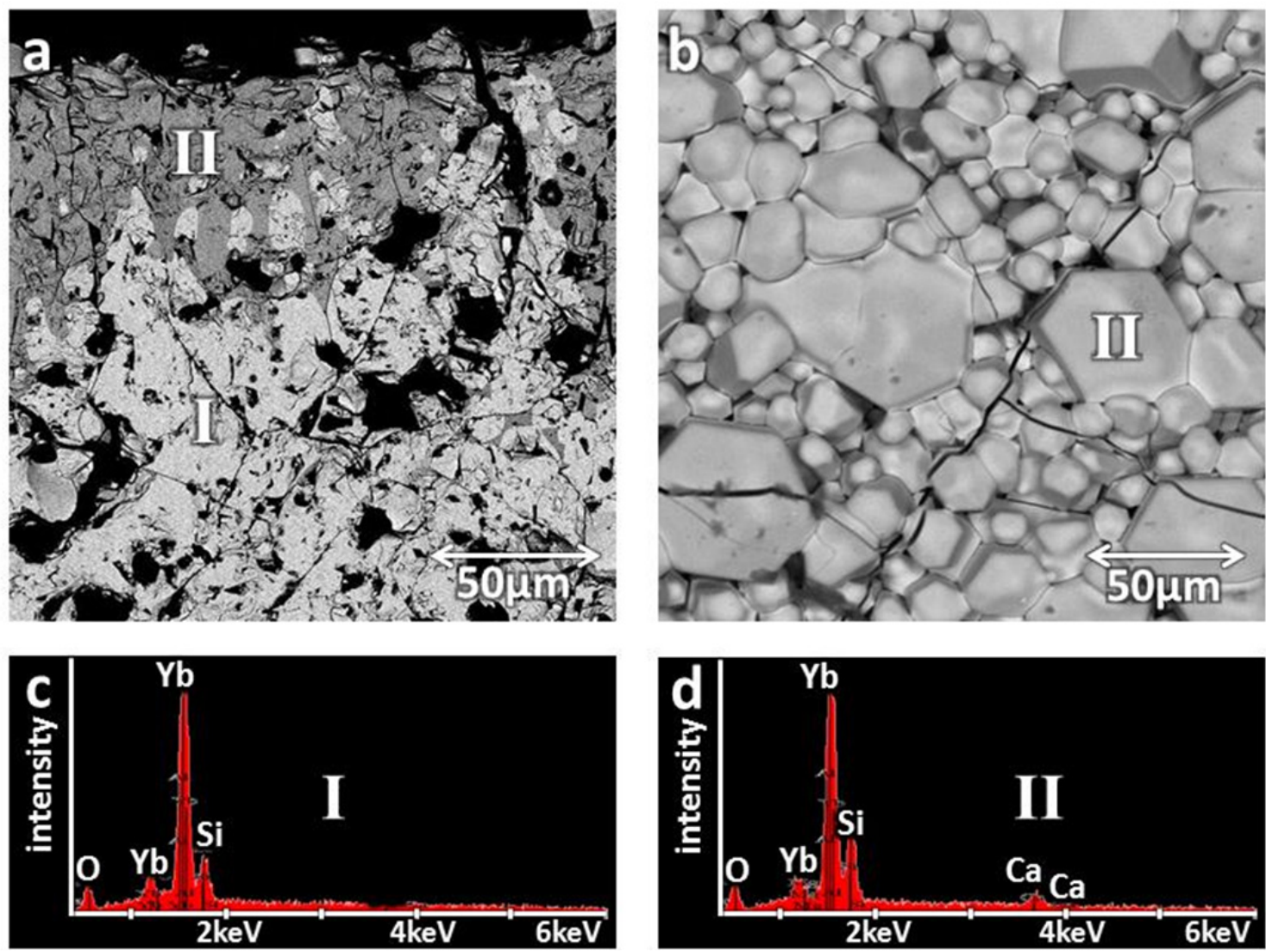

Figure 3.-SEM micrographs of $\mathrm{Yb}_{2} \mathrm{SiO}_{5}$ reacted with CMAS for 50 h. (a) cross-section; (b) surface BSE images of $\mathrm{Yb}_{2} \mathrm{SiO}_{5}$ reacted with CMAS for $50 \mathrm{~h}$ at $1500{ }^{\circ} \mathrm{C}$; (c) and (d) EDS of regions I and II, respectively. 

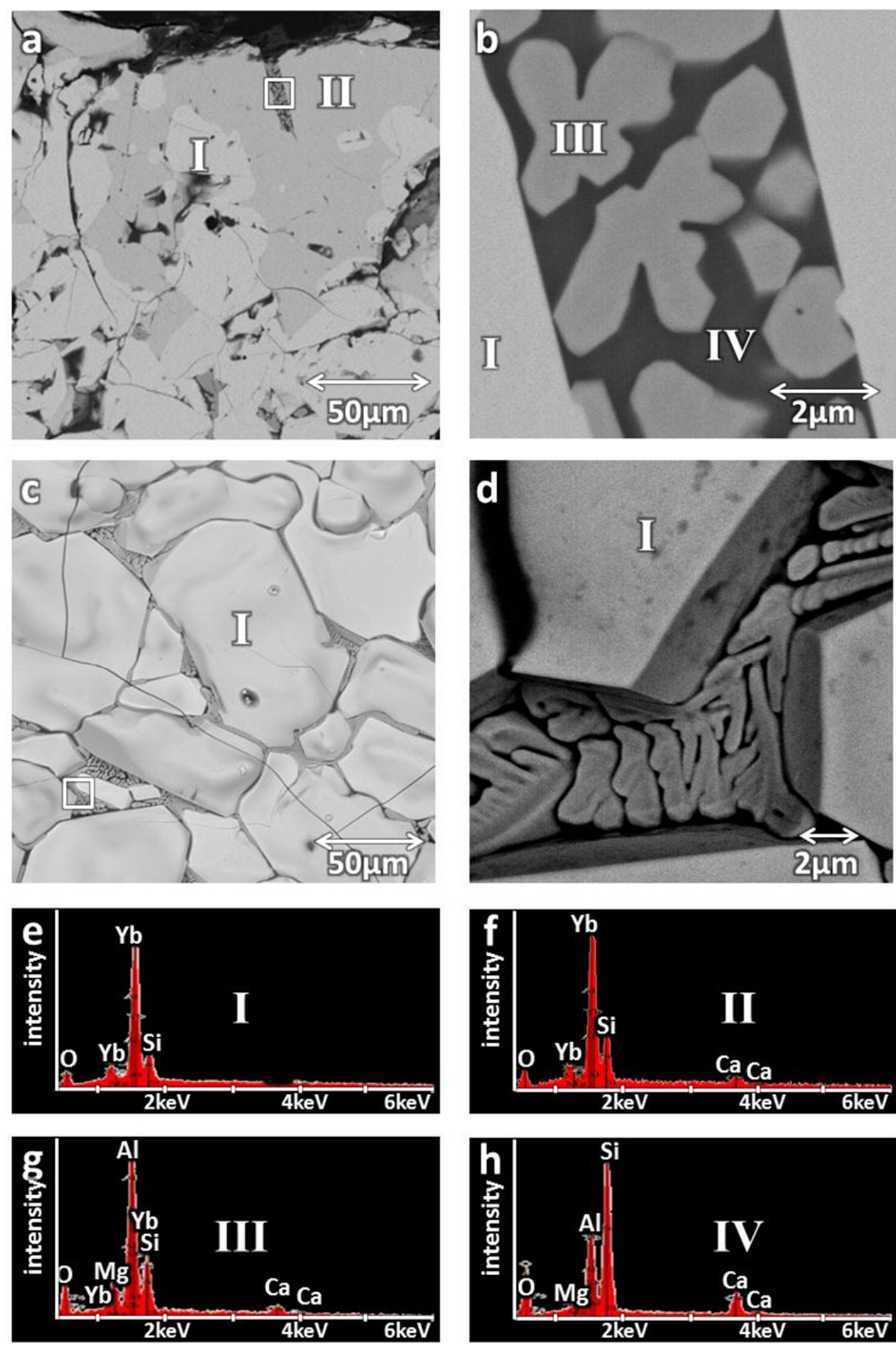

Figure 4.-SEM images of $\mathrm{Yb}_{2} \mathrm{SiO}_{5}$ reacted with CMAS for $200 \mathrm{~h}$. (a), (b), (c), and (d) low and high magnification surface BSE images of $\mathrm{Yb}_{2} \mathrm{SiO}_{5}$ reacted with CMAS for $200 \mathrm{~h}$ at $1500^{\circ} \mathrm{C}$; and (e) and (h) EDS of regions I-IV, respectively. 


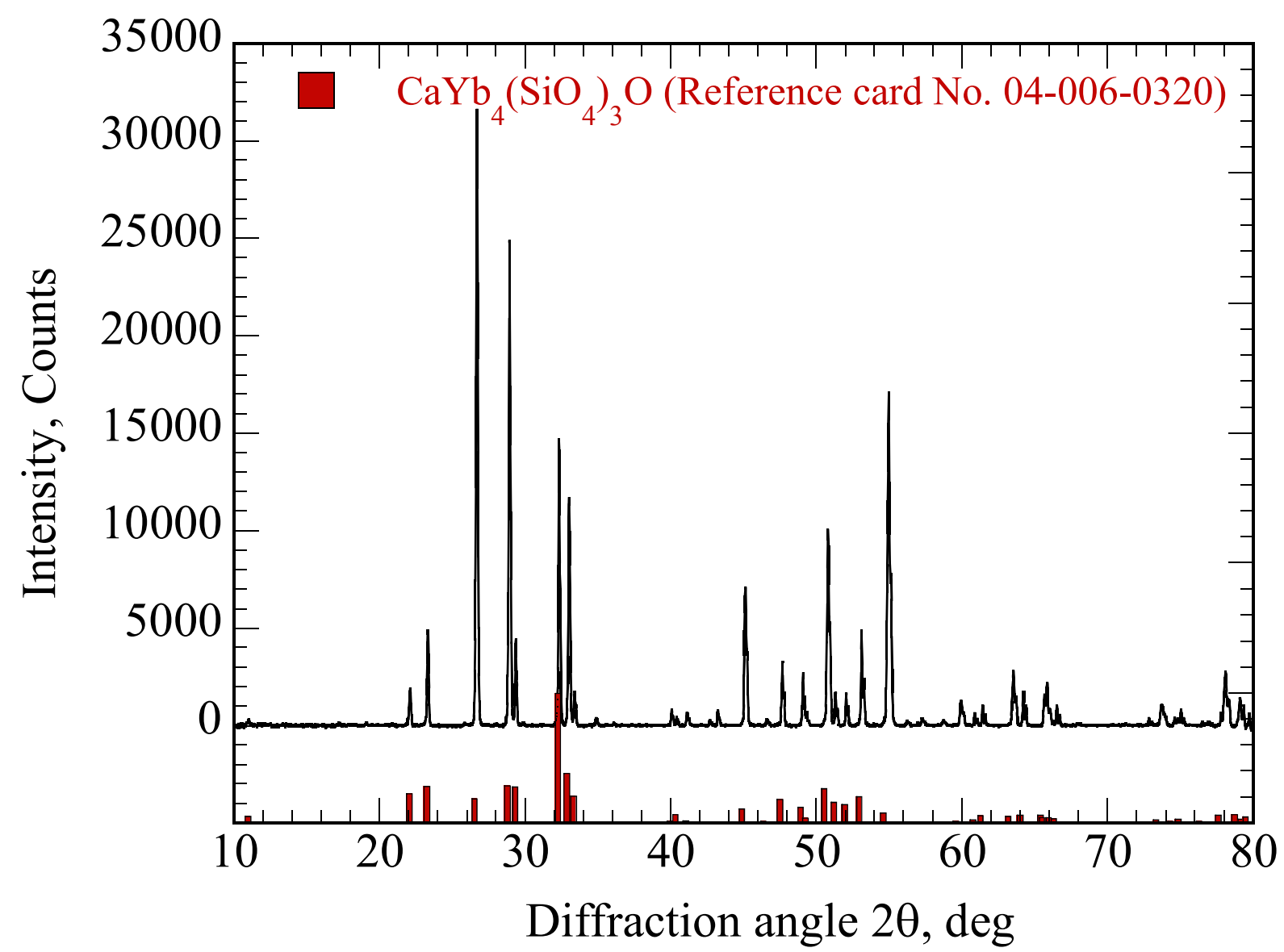

Figure 5.-XRD of $\mathrm{Yb}_{2} \mathrm{SiO}_{5}-\mathrm{CMAS}$ reaction layer. The pattern for $\mathrm{Ca}_{2} \mathrm{Yb}_{8}\left(\mathrm{SiO}_{4}\right)_{6} \mathrm{O}_{2}$ matches well with the observed $\mathrm{X}$-ray scan for the $\mathrm{Yb}_{2} \mathrm{SiO}_{5}$-CMAS reaction layer.
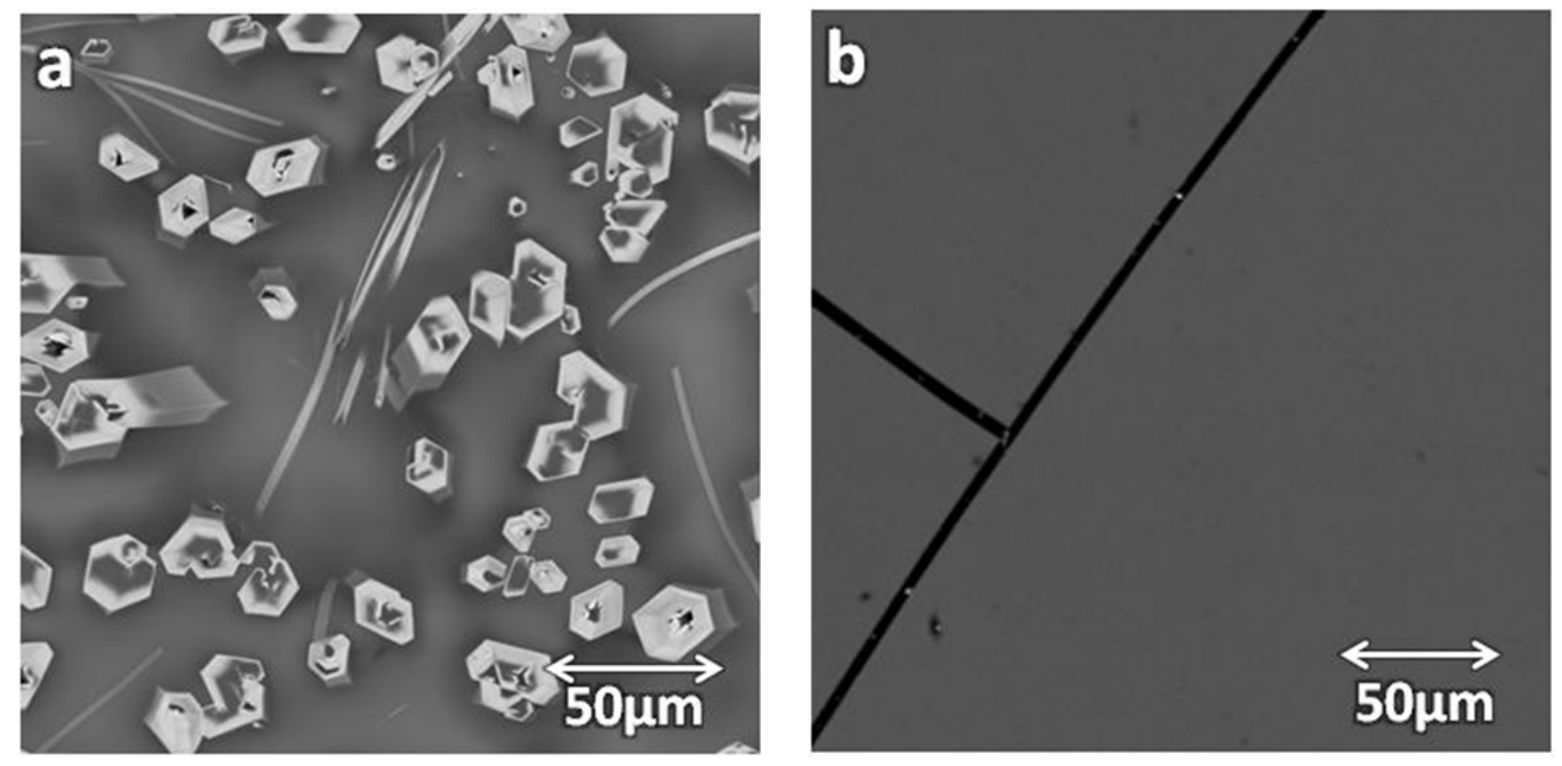

Figure 6. $-\mathrm{Yb}_{2} \mathrm{SiO}_{5}$ surface reacted with CMAS for (a) $5 \mathrm{~h}$ at $1500^{\circ} \mathrm{C}$ and (b) $50 \mathrm{~h}$ at $1300^{\circ} \mathrm{C}$. 


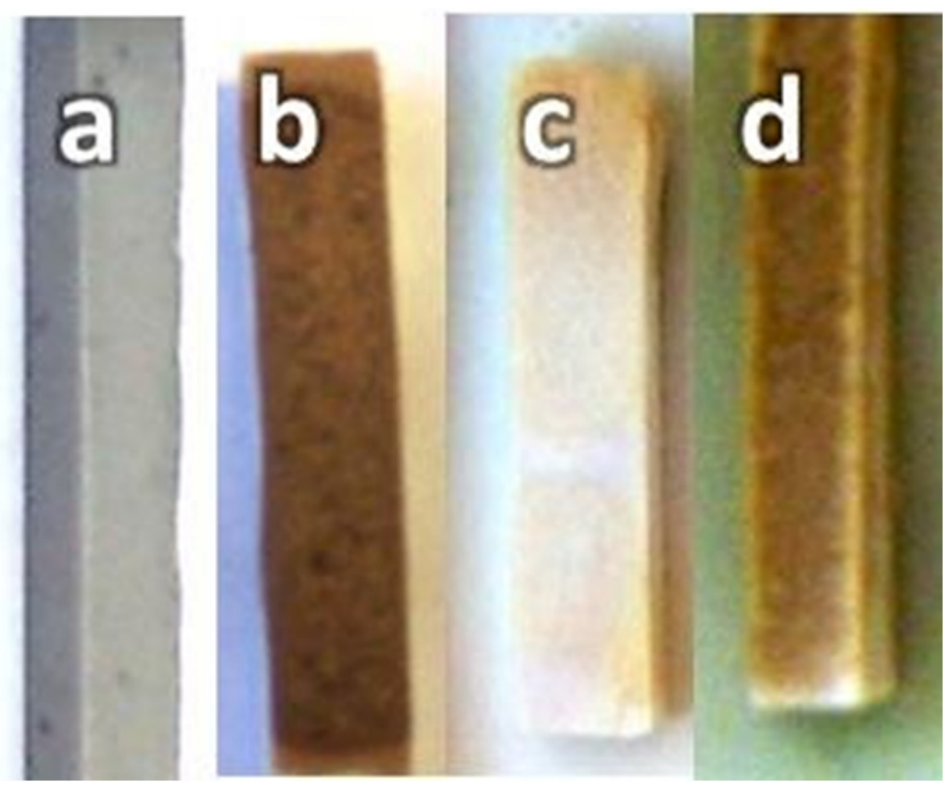

Figure 7.-Photographs of $\mathrm{Y}_{2} \mathrm{Si}_{2} \mathrm{O}_{7}$ specimens reacted with CMAS for various time at $1500{ }^{\circ} \mathrm{C}$. (a) as-sintered; and (b) reacted with CMAS for $5 \mathrm{~h}$, (c) $50 \mathrm{~h}$, and (d) $200 \mathrm{~h}$. Due to the volatility of the CMAS and its melts at high temperature, the amount of CMAS for reactions was not sustainable for the long-term testing at $1500{ }^{\circ} \mathrm{C}$ in atmospheric pressure in air.
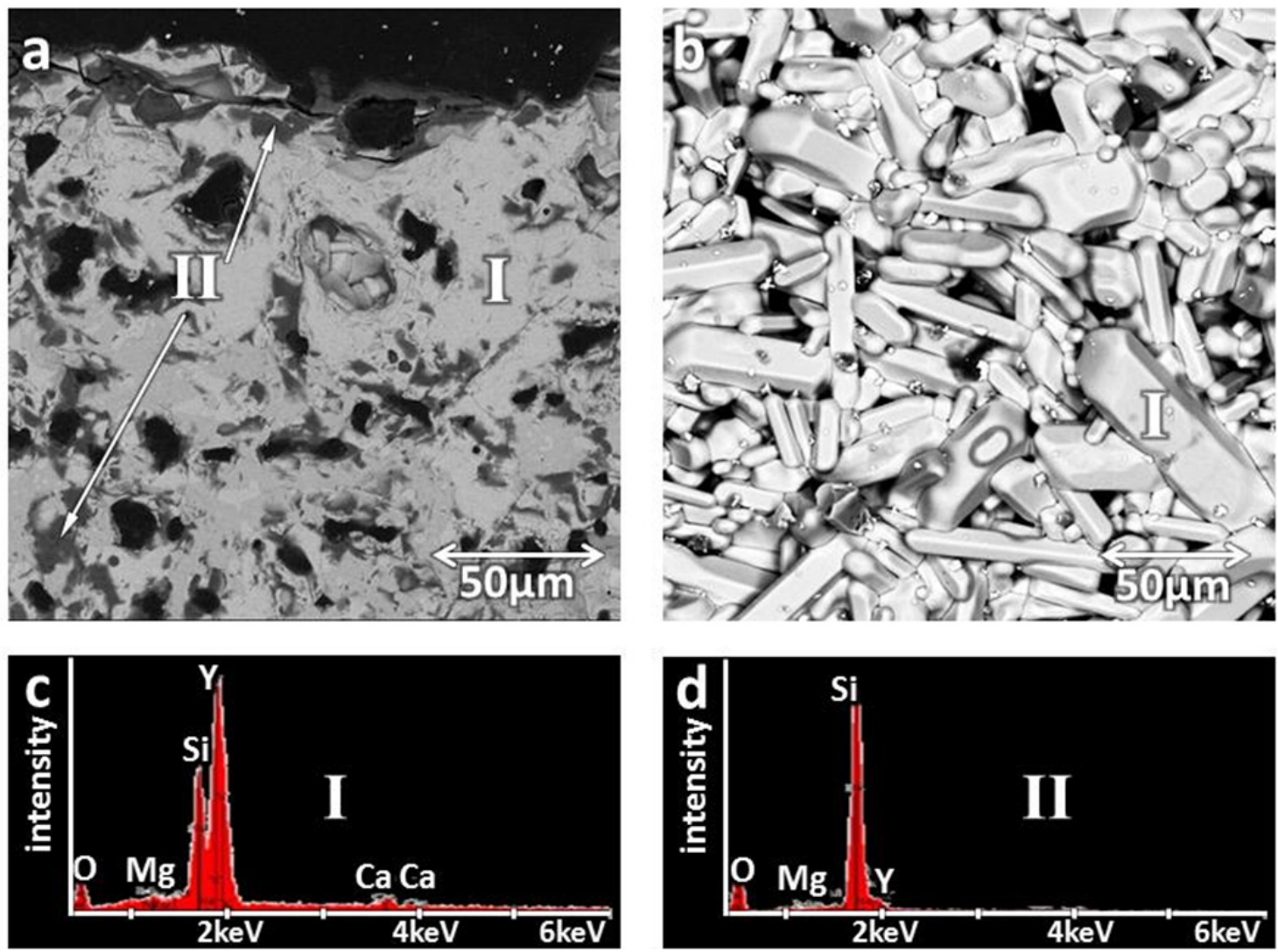

Figure 8. $-\mathrm{Y}_{2} \mathrm{Si}_{2} \mathrm{O}_{7}$ reacted with CMAS for $50 \mathrm{~h}$ at $1500{ }^{\circ} \mathrm{C}$. (a) A cross-section SEM BSE image of the $\mathrm{Y}_{2} \mathrm{Si}_{2} \mathrm{O}_{7}$; (b) A surface SEM BSE image of the $\mathrm{Y}_{2} \mathrm{Si}_{2} \mathrm{O}_{7}$; (c) and (d) EDS analyses of regions I and II in the cross-section surface, respectively. 

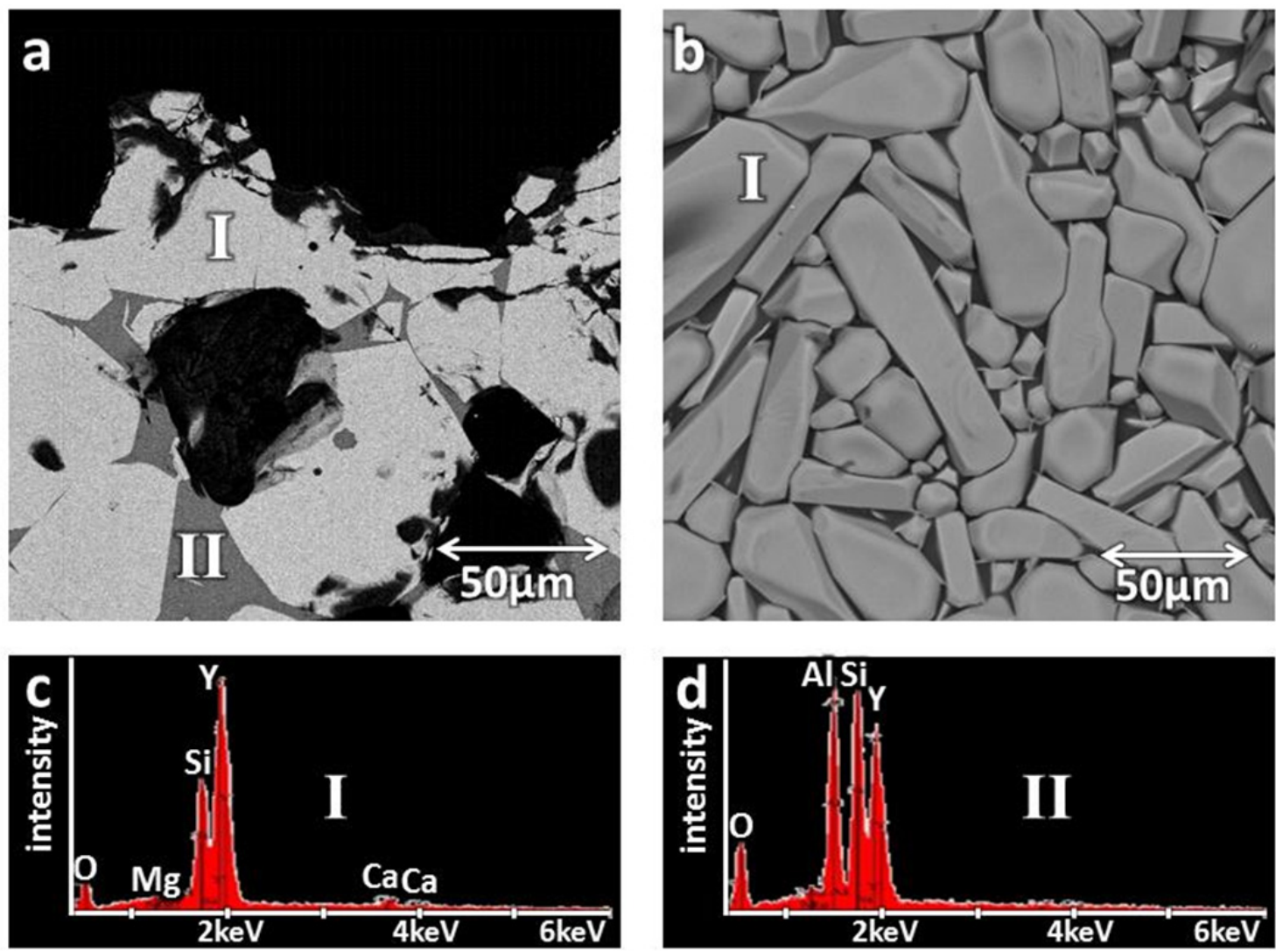

Figure 9.- $\mathrm{Y}_{2} \mathrm{Si}_{2} \mathrm{O}_{7}$ reacted with CMAS for $200 \mathrm{~h}$ at $1500{ }^{\circ} \mathrm{C}$. (a) A cross-section SEM BSE image of the $\mathrm{Y}_{2} \mathrm{Si}_{2} \mathrm{O}_{7}$; (b) A surface SEM BSE image of the $\mathrm{Y}_{2} \mathrm{Si}_{2} \mathrm{O}_{7}$; (c) and (d) EDS analyses of regions I and II in the cross-section surface, respectively.

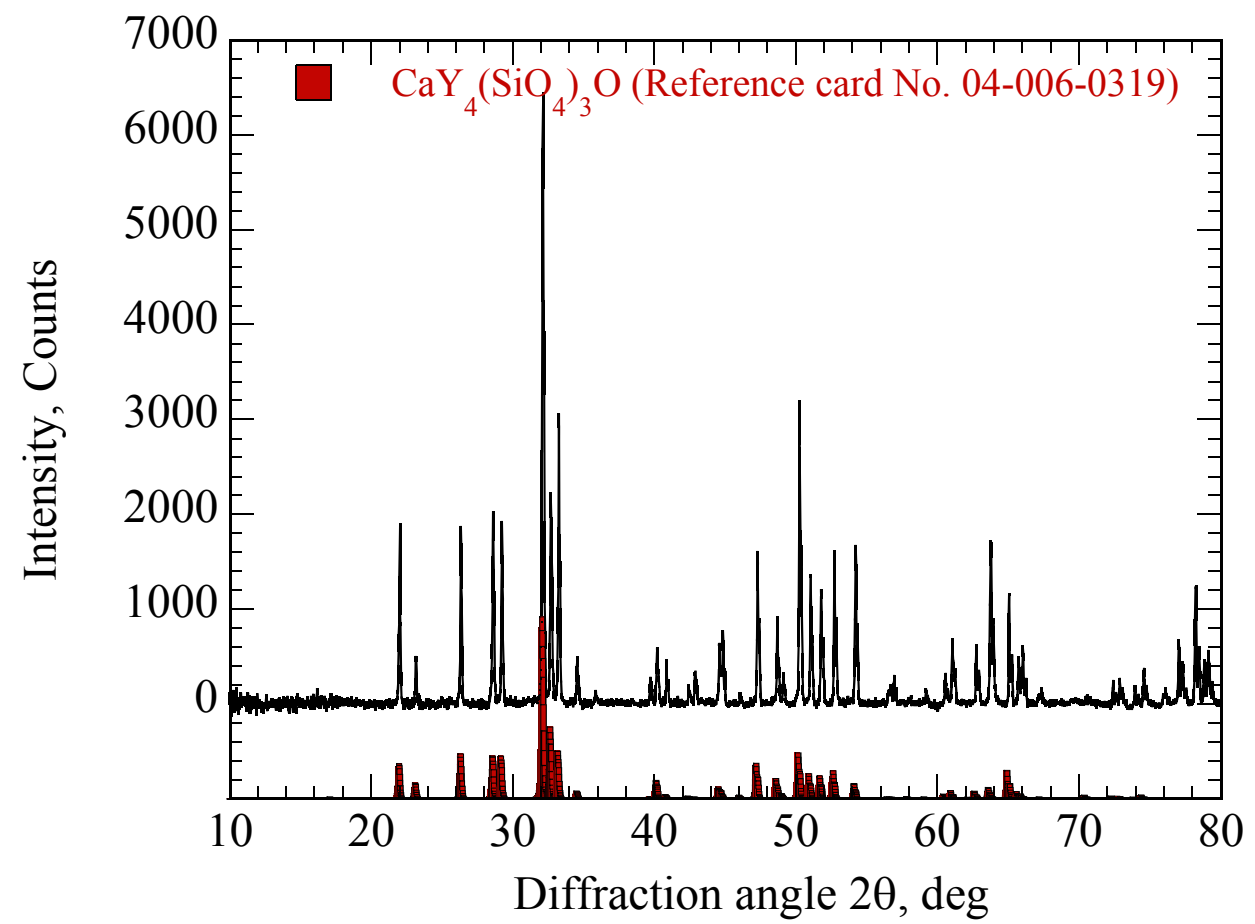

Figure 10.-XRD of $\mathrm{Y}_{2} \mathrm{Si}_{2} \mathrm{O}_{7}$-CMAS reaction product. The pattern for $\mathrm{Ca}_{2} \mathrm{Y}_{8}\left(\mathrm{SiO}_{4}\right)_{6} \mathrm{O}_{2}$ matches. 

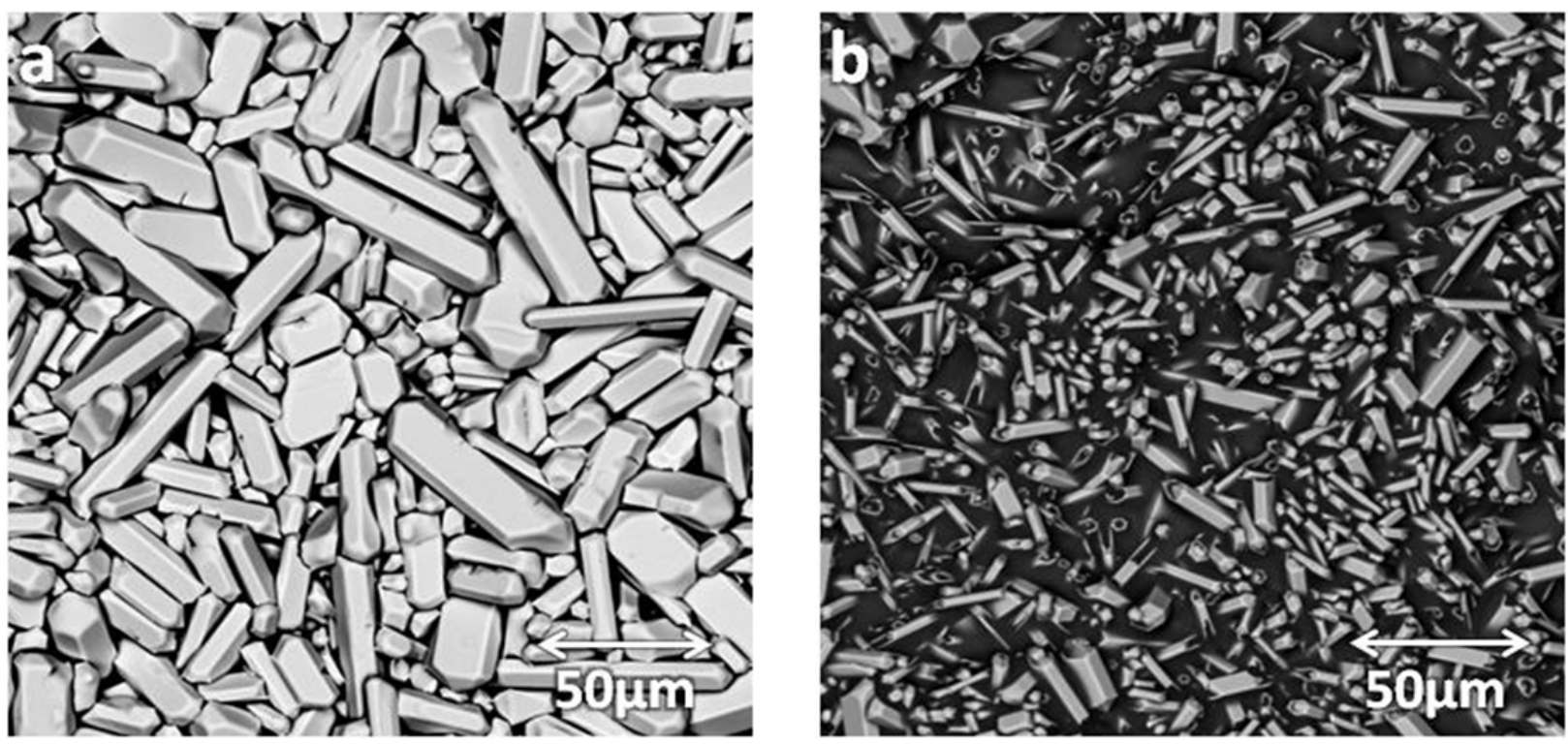

Figure 11. $-\mathrm{Y}_{2} \mathrm{Si}_{2} \mathrm{O}_{7}$ reacted with CMAS for (a) $5 \mathrm{~h}$ at $1500{ }^{\circ} \mathrm{C}$ and (b) $50 \mathrm{~h}$ at $1300{ }^{\circ} \mathrm{C}$.
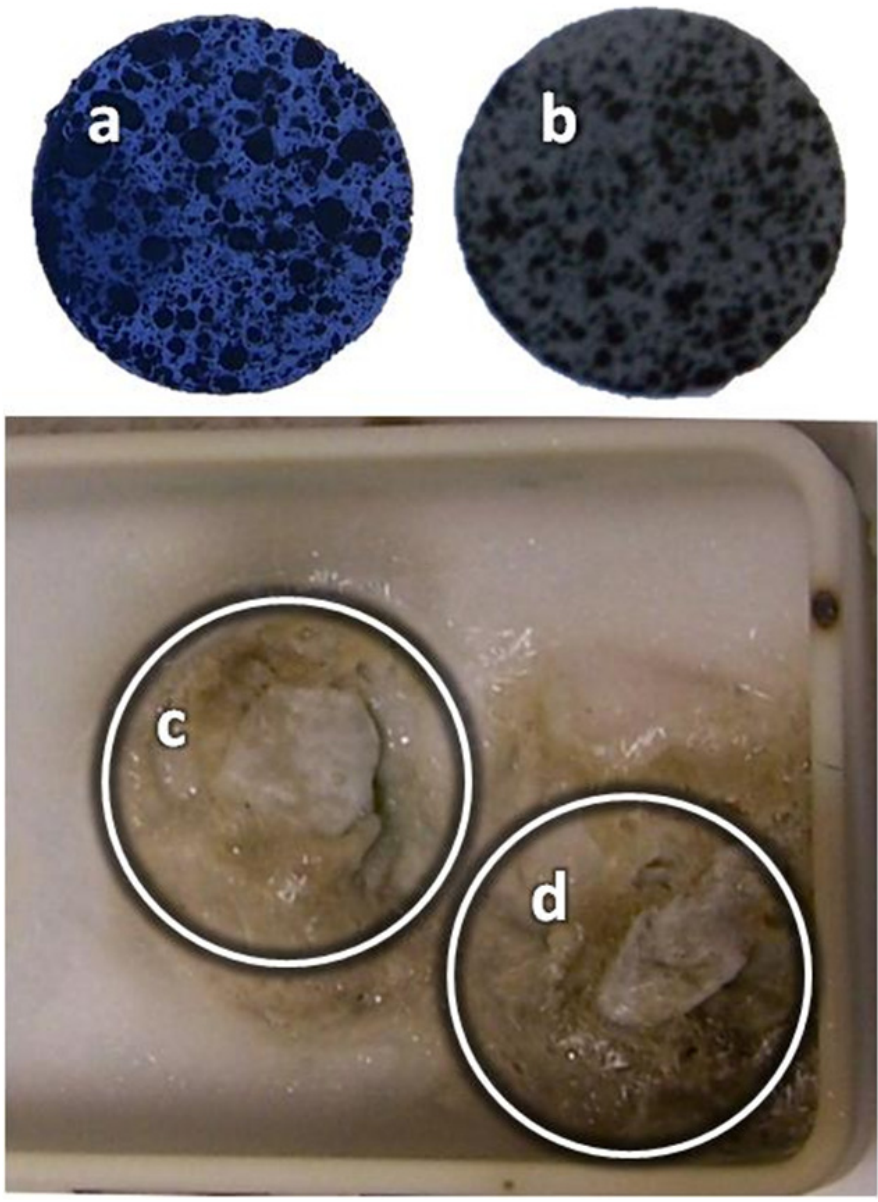

Figure 12.-RE-silicate + CMAS mixtures. Digital photographs of (a) $\mathrm{Yb}_{2} \mathrm{SiO}_{5}+25 \mathrm{wt} \%$ CMAS as-sintered; (b) $\mathrm{Y}_{2} \mathrm{Si}_{2} \mathrm{O}_{7}+$ $30 \mathrm{wt} \%$ CMAS as-sintered; (c) $\mathrm{Yb}_{2} \mathrm{SiO}_{5}+25 \mathrm{wt} \%$ CMAS heat treated for $50 \mathrm{~h}$ at $1500{ }^{\circ} \mathrm{C}$; and (d) $\mathrm{Y}_{2} \mathrm{Si}_{2} \mathrm{O}_{7}+30 \mathrm{wt} \%$ CMAS heat treated for $50 \mathrm{~h}$ at $1500^{\circ} \mathrm{C}$. 

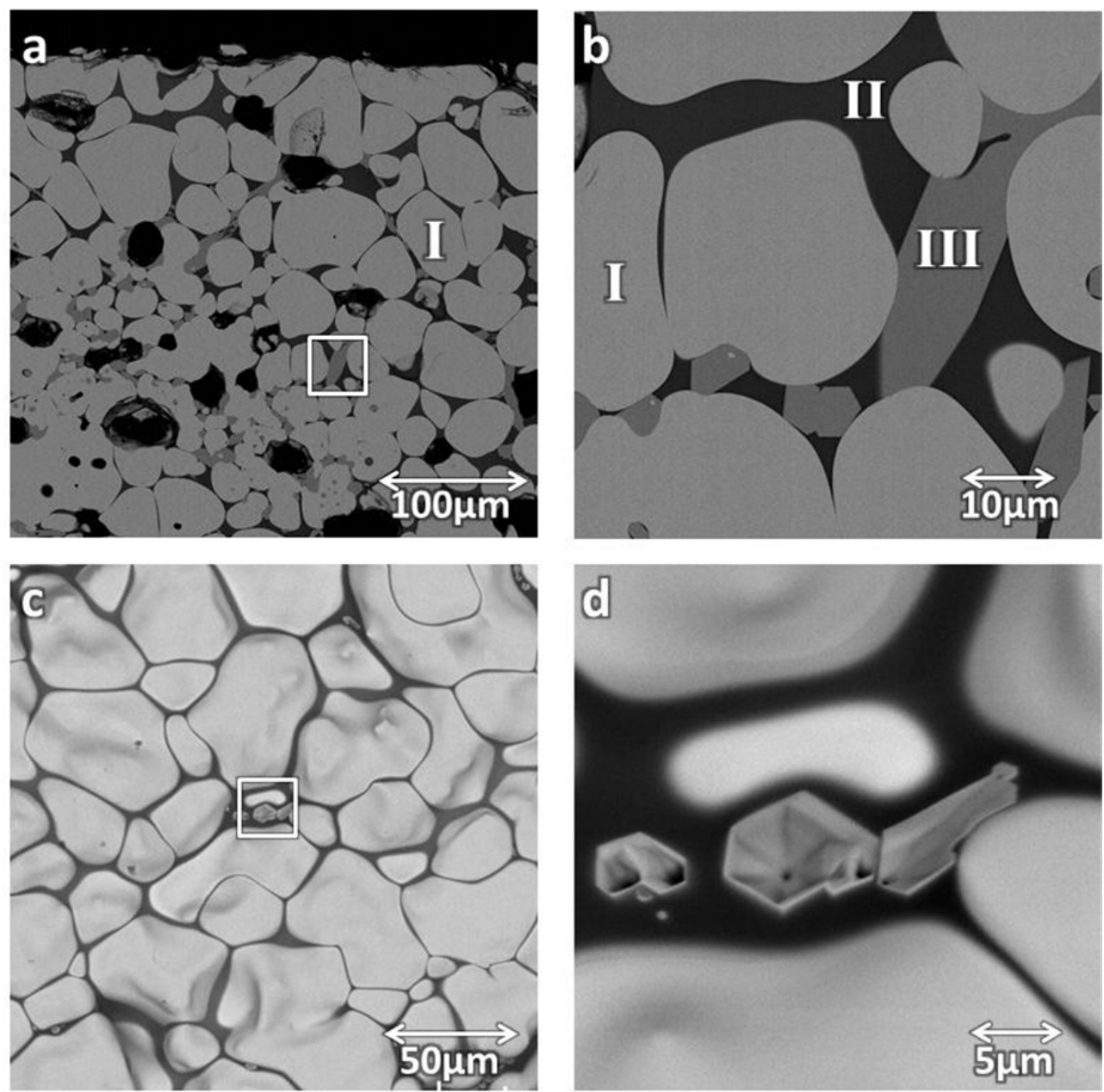

Figure 13.- $-\mathrm{HfO}_{2}$ reacted with CMAS for $100 \mathrm{~h}$. (a) and (b) Low and high magnification cross-sectional images of RE-oxide doped $\mathrm{HfO}_{2}$ reacted with CMAS for $100 \mathrm{~h}$ at $1500{ }^{\circ} \mathrm{C}$; (c) and (d) Low and high magnification surface BSE images of RE-oxide doped $\mathrm{HfO}_{2}$ reacted with CMAS for $100 \mathrm{~h}$ at $1500{ }^{\circ} \mathrm{C}$. Similar to the rare earth silicate cases, the high concentration rare earth doped $\mathrm{HfO}_{2}$ had relatively substantial grain boundary recessions and CMAS reaction phases. 

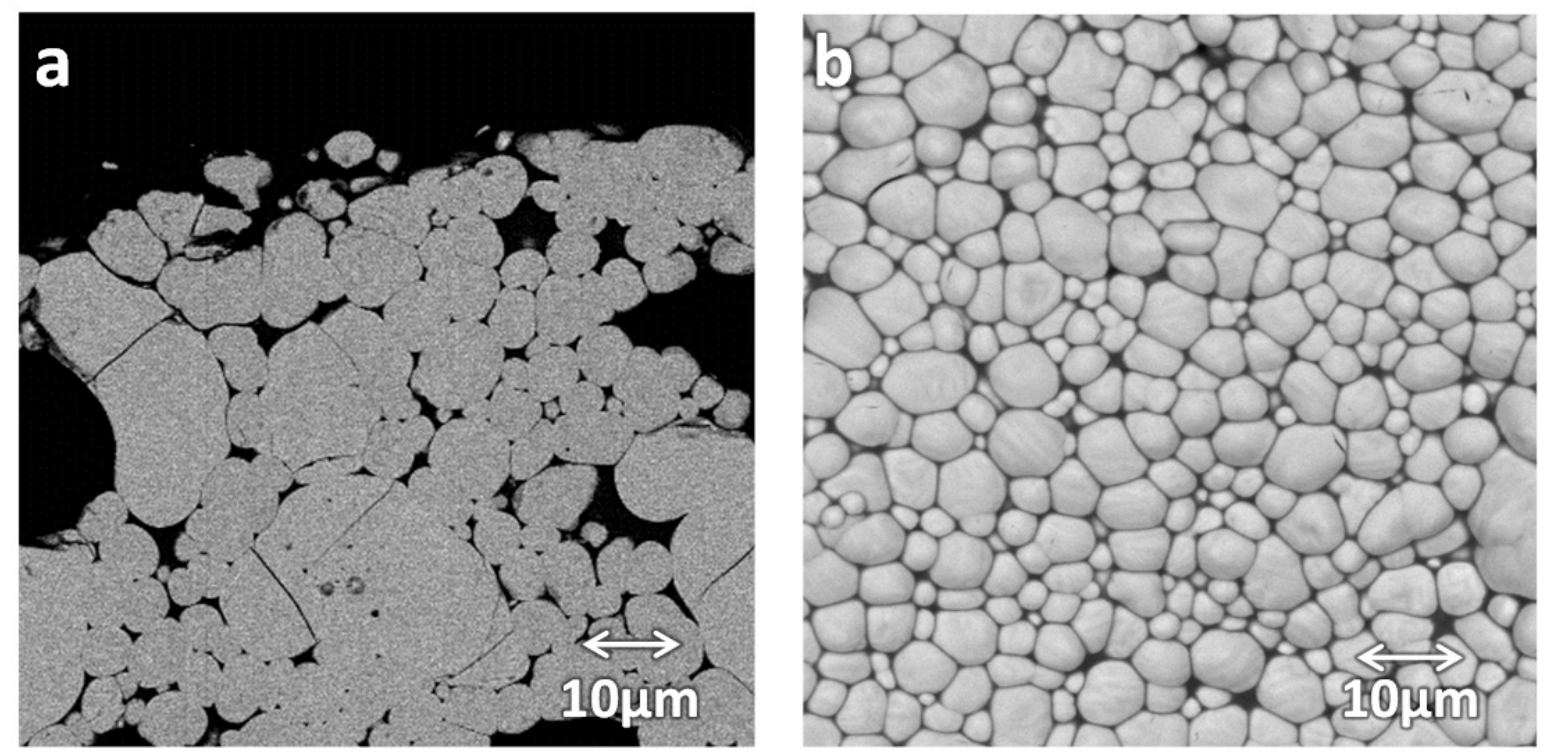

Figure 14.- $\mathrm{ZrO}_{2}$ reacted with CMAS for $100 \mathrm{~h}$ at $1500{ }^{\circ} \mathrm{C}$. (a) A cross-sectional image of six-component $\mathrm{RE}$ oxide-doped $\mathrm{ZrO}_{2}$ reacted with CMAS; (b) A surface BSE image of six-component RE oxide-doped $\mathrm{ZrO}_{2}$ reacted with CMAS.

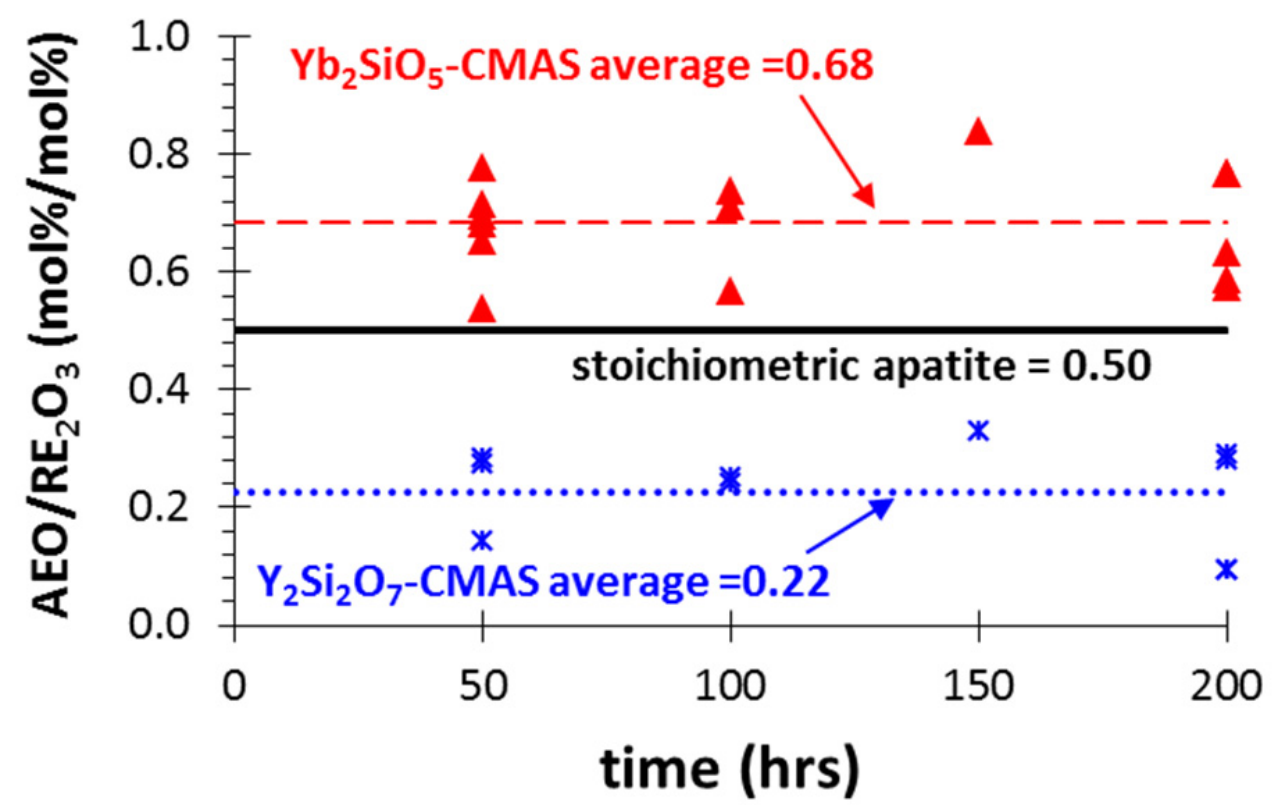

Figure 15.-Stoichiometry of CMAS reaction layers. The molar ratio of alkaline earthoxides (AEO) $\mathrm{CaO}+\mathrm{MgO}$ to rare earth-oxides $\left(\mathrm{RE}_{2} \mathrm{O}_{3}\right) \mathrm{Yb}_{2} \mathrm{O}_{3}$ and $\mathrm{Yb}_{2} \mathrm{O}_{3}$ in the $\mathrm{Yb}_{2} \mathrm{SiO}_{5}-$ CMAS and $\mathrm{Y}_{2} \mathrm{Si}_{2} \mathrm{O}_{7}-\mathrm{CMAS}$ reaction layers as a function of time. The average and stoichiometric molar ratios are indicated as horizontal lines. 


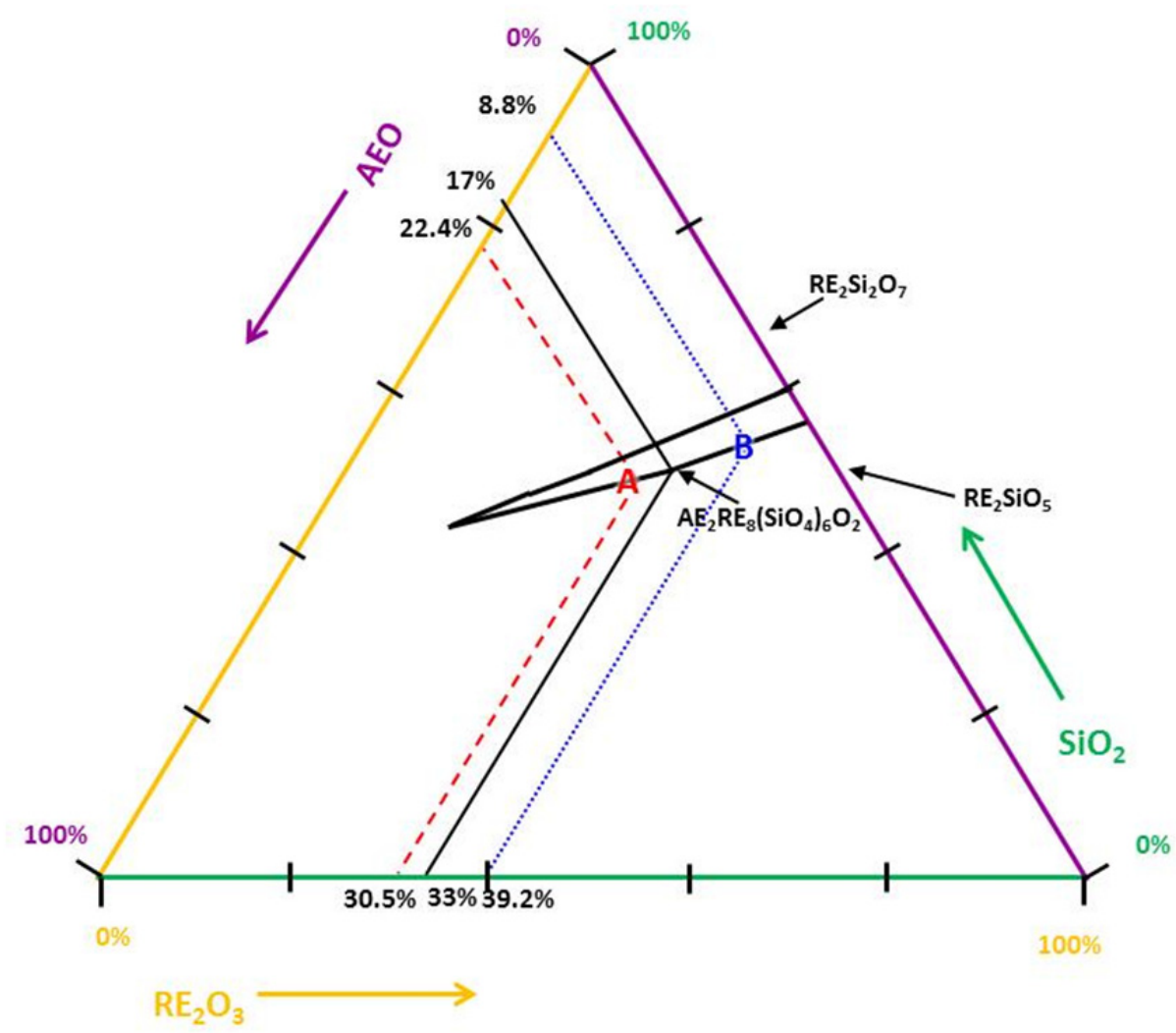

Figure 16.-AEO- $\mathrm{RE}_{2} \mathrm{O}_{3}-\mathrm{SiO}_{2}$ phase diagram. Redrawn ternary phase diagram 13 indicating shifted non-stoichiometric apatite compositions. The letters $\mathrm{A}$ and $\mathrm{B}$ indicate the compositions of CMAS- reacted $\mathrm{Yb}_{2} \mathrm{SiO}_{5}$ and $\mathrm{Y}_{2} \mathrm{Si}_{2} \mathrm{O}_{7}$, respectively. 



\begin{tabular}{|c|c|c|}
\hline \multicolumn{2}{|c|}{ REPORT DOCUMENTATION PAGE } & $\begin{array}{l}\text { Form Approved } \\
\text { OMB No. 0704-0188 }\end{array}$ \\
\hline \multicolumn{3}{|c|}{ 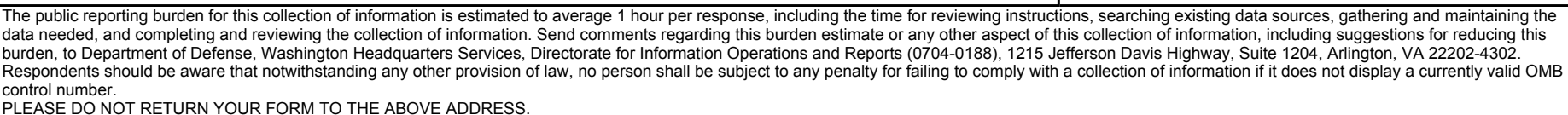 } \\
\hline $\begin{array}{l}\text { 1. REPORT DATE (DD-MM-YYYY) } \\
01-11-2013\end{array}$ & $\begin{array}{l}\text { 2. REPORT TYPE } \\
\text { Technical Memorandum }\end{array}$ & 3. DATES COVERED (From - To) \\
\hline \multirow{3}{*}{\multicolumn{2}{|c|}{$\begin{array}{l}\text { 4. TITLE AND SUBTITLE } \\
\text { Calcium-Magnesium-Aluminosilicate (CMAS) Reactions and Degradation Mechanisms of } \\
\text { Advanced Environmental Barrier Coatings }\end{array}$}} & 5a. CONTRACT NUMBER \\
\hline & & 5b. GRANT NUMBER \\
\hline & & 5c. PROGRAM ELEMENT NUMBER \\
\hline \multirow{3}{*}{\multicolumn{2}{|c|}{$\begin{array}{l}\text { 6. AUTHOR(S) } \\
\text { Ahlborg, Nadia, L.; Zhu, Dongming }\end{array}$}} & 5d. PROJECT NUMBER \\
\hline & & 5e. TASK NUMBER \\
\hline & & $\begin{array}{l}\text { 5f. WORK UNIT NUMBER } \\
\text { WBS 794072.02.03.03.02 }\end{array}$ \\
\hline \multicolumn{2}{|c|}{$\begin{array}{l}\text { 7. PERFORMING ORGANIZATION NAME(S) AND ADDRESS(ES) } \\
\text { National Aeronautics and Space Administration } \\
\text { John H. Glenn Research Center at Lewis Field } \\
\text { Cleveland, Ohio 44135-3191 }\end{array}$} & $\begin{array}{l}\text { 8. PERFORMING ORGANIZATION } \\
\text { REPORT NUMBER } \\
\text { E-18789 }\end{array}$ \\
\hline \multirow{2}{*}{\multicolumn{2}{|c|}{$\begin{array}{l}\text { 9. SPONSORING/MONITORING AGENCY NAME(S) AND ADDRESS(ES) } \\
\text { National Aeronautics and Space Administration } \\
\text { Washington, DC 20546-0001 }\end{array}$}} & $\begin{array}{l}\text { 10. SPONSORING/MONITOR'S } \\
\text { ACRONYM(S) } \\
\text { NASA }\end{array}$ \\
\hline & & $\begin{array}{l}\text { 11. SPONSORING/MONITORING } \\
\text { REPORT NUMBER } \\
\text { NASA/TM-2013-218091 }\end{array}$ \\
\hline \multicolumn{3}{|c|}{$\begin{array}{l}\text { 12. DISTRIBUTION/AVAILABILITY STATEMENT } \\
\text { Unclassified-Unlimited } \\
\text { Subject Categories: } 23,24 \text {, and } 27 \\
\text { Available electronically at http://www.sti.nasa.gov } \\
\text { This publication is available from the NASA Center for AeroSpace Information, 443-757-5802 }\end{array}$} \\
\hline
\end{tabular}

\section{SUPPLEMENTARY NOTES}

\section{ABSTRACT}

The thermochemical reactions between calcium-magnesium-aluminosilicate- (CMAS-) based road sand and several advanced turbine engine environmnetal barrier coating (EBC) materials were studied. The phase stability, reaction kinetics and degradation mechanisms of rare earth (RE)-silicates $\mathrm{Yb}_{2} \mathrm{SiO}_{5}, \mathrm{Y}_{2} \mathrm{Si}_{2} \mathrm{O}_{7}$, and RE-oxide doped $\mathrm{HfO}_{2}$ and $\mathrm{ZrO}_{2}$ under the CMAS infiltration condition at $1500{ }^{\circ} \mathrm{C}$ were investigated, and the microstructure and phase characteristics of CMAS-EBC specimens were examined using Scanning Electron Microscopy (SEM) and X-ray Diffraction (XRD). Experimental results showed that the CMAS dissolved RE-silicates to form crystalline, highly non-stoichiometric apatite phases, and in particular attacking the silicate grain boundaries. Cross-section images show that the CMAS reacted with specimens and deeply penetrated into the EBC grain boundaries and formed extensive low-melting eutectic phases, causing grain boundary recession with increasing testing time in the silicate materials. The preliminary results also showed that CMAS reactions also formed low melting grain boundary phases in the higher concentration RE-oxide doped $\mathrm{HfO}_{2}$ systems. The effect of the test temperature on CMAS reactions of the EBC materials will also be discussed. The faster diffusion exhibited by apatite and RE-doped oxide phases and the formation of extensive grain boundary low-melting phases may limit the CMAS resistance of some of the environmental barrier coatings at high temperatures.

\section{SUBJECT TERMS}

Environmental barrier coatings; Calcium-Magnesium Aluminosilicate; Ytterbium silicate; Yttrium silicate; Hafnia; Zirconia; Apatite; Glass

\begin{tabular}{|c|c|c|c|c|c|}
\hline \multicolumn{3}{|c|}{ 16. SECURITY CLASSIFICATION OF: } & \multirow{2}{*}{$\begin{array}{l}\text { 17. LIMITATION OF } \\
\text { ABSTRACT } \\
\text { UU }\end{array}$} & \multirow{2}{*}{$\begin{array}{l}\text { 18. NUMBER } \\
\text { OF } \\
\text { PAGES } \\
24\end{array}$} & \multirow{2}{*}{$\begin{array}{l}\text { 19a. NAME OF RESPONSIBLE PERSON } \\
\text { STI Help Desk (email:help@sti.nasa.gov) } \\
\text { 19b. TELEPHONE NUMBER (include area code) } \\
\text { 443-757-5802 }\end{array}$} \\
\hline $\begin{array}{l}\text { a. REPORT } \\
U\end{array}$ & $\begin{array}{l}\text { b. ABSTRACT } \\
U\end{array}$ & $\begin{array}{l}\text { c. THIS } \\
\text { PAGE } \\
\text { U }\end{array}$ & & & \\
\hline
\end{tabular}



